
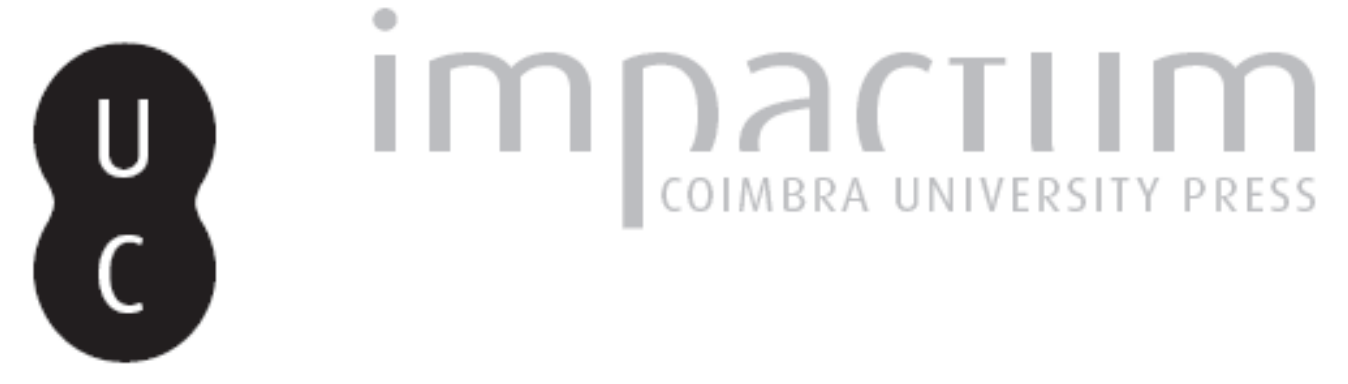

\title{
Obras de correção torrencial no controlo de situações de erosão hídrica em Portugal: exemplos da Bacia hidrográfica do Rio Pranto (Baixo Mondego)
}
Autor(es):
Bernardino, Sofia; Lourenço, Luciano
Publicado por: Associação Portuguesa de Riscos, Prevenção e Segurança
URL persistente:
URI:http://hdl.handle.net/10316.2/35843
DOI:
DOI:http://dx.doi.org/10.14195/1647-7723_20_10
Accessed :
26-Apr-2023 10:58:51

A navegação consulta e descarregamento dos títulos inseridos nas Bibliotecas Digitais UC Digitalis, UC Pombalina e UC Impactum, pressupõem a aceitação plena e sem reservas dos Termos e Condições de Uso destas Bibliotecas Digitais, disponíveis em https://digitalis.uc.pt/pt-pt/termos.

Conforme exposto nos referidos Termos e Condições de Uso, o descarregamento de títulos de acesso restrito requer uma licença válida de autorização devendo o utilizador aceder ao(s) documento(s) a partir de um endereço de IP da instituição detentora da supramencionada licença.

Ao utilizador é apenas permitido o descarregamento para uso pessoal, pelo que o emprego do(s) título(s) descarregado(s) para outro fim, designadamente comercial, carece de autorização do respetivo autor ou editor da obra.

Na medida em que todas as obras da UC Digitalis se encontram protegidas pelo Código do Direito de Autor e Direitos Conexos e demais legislação aplicável, toda a cópia, parcial ou total, deste documento, nos casos em que é legalmente admitida, deverá conter ou fazer-se acompanhar por este aviso.

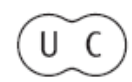




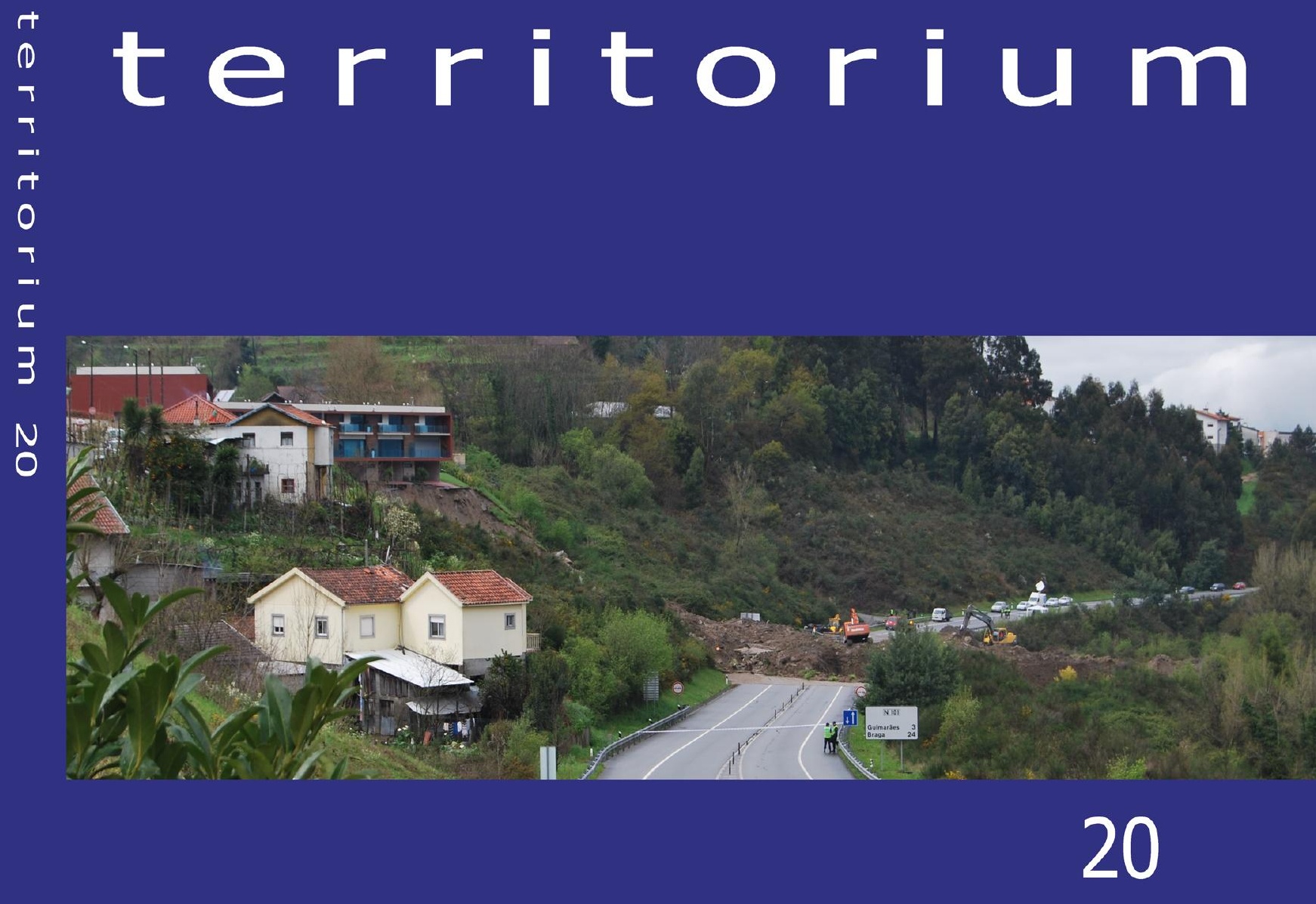

Riscos, População e Segurança 


\section{OBRAS DE CORREÇÃO TORRENCIAL NO CONTROLO DE STTUAÇÕES DE EROSÃO HÍDRICA EM PORTUGAL. EXEMPLOS DA BACIA HIDROGRÁFICA DO RIO PRANTO (BAIXO MONDEGO)*}

Sofia Bernardino

NICIF - Núcleo de Investigação Científica de Incêndios Florestais sofia.bernardino@yahoo.com

Luciano Lourenço

NICIF - Núcleo de Investigação Científica de Incêndios Florestais e Departamento de Geografia da Faculdade de Letras da Universidade de Coimbra

luciano@uc.pt

\section{RESUMO}

Os trabalhos de defesa e conservação do solo, em Portugal, tiveram um notável incremento a partir de 1941. Conscientes de que a subsistência do homem dependia da terra e de que os processos erosivos associados à ação da água proveniente da pluviosidade degradavam, paulatinamente, os recursos edáficos, várias foram as obras de correção torrencial levadas a cabo em todo o País. Este trabalho surge assim com o objetivo de divulgação das obras realizadas e, principalmente, das técnicas mais utilizadas na correção da erosão hídrica, através de exemplos concretos na Bacia Hidrográfica do Rio Pranto (Baixo Mondego).

Palavras-chave: Conservação do solo, correção torrencial, erosão hídrica, bacia hidrográfica do rio Pranto.

\section{RESUMEN}

Las obras de corrección torrencial en situaciones de control de la erosión en Portugal. Ejemplos de la cuenca del río Pranto (Bajo Mondego) - Las obras de defensa y conservación de suelos en Portugal, sufrió un notable incremiento desde 1941. Consciente de que la vida del hombre depende de la tierra y la erosión asociada a la acción del agua de lluvia degradan poco a poco, los recursos edáficos, varias obras de corrección torrencial se llevaron a cabo en todo el país. Este trabajo aparece así dirigido a la difusión de las obras, y en especial las técnicas más utilizadas en la corrección de la erosión, a través de ejemplos concretos en la cuenca del Río Pranto (Bajo Mondego).

Palabras clave: Conservación de suelos, corrección torrencial, erosión, cuenca del río Pranto.

\section{RÉSUMÉ}

Les travaux de correction torrentiel dans les situations de lutte contre l'erosion de l'eau au Portugal. Exemples du bassin de la rivière Pranto (Basse Mondego) - Les travaux de défense et conservation des sols au Portugal, ont connu une augmentation notable après 1941. Avec la conscience que les moyens de subsistance de l'homme dépandaient de la terre et que les processus d'érosion associés à l'action de l'eau de pluie dégradent, lentement, les ressources édaphiques, plusieurs travaux de correction torrentielle ont été effectués dans tout le pays. Ce travail a pour objectif la diffusion des travaux réalisés et, en particulier, des techniques les plus utilisées dans la correction de l'érosion, à travers des exemples concrets dans le bassin de la rivière Pranto (Bas-Mondego).

Mots-clé: Conservation des sols, correction torrentielle, érosion, bassin de la rivière Pranto.

\section{ABSTRACT}

The works of torrential correction in control of erosion situations in Portugal. Examples of Pranto river basin (low Mondego) - The defense works and soil conservation in Portugal had a notable increase from 1941. Aware that the man's livelihood depended on the land and the erosion associated with the action of water from rainfall degrade gradually, edaphic resources, many works were torrential correction carried out across the country. This article appears with the purpose of divulgation of works performed, and especially the most used techniques in correcting erosion, through specific examples in Pranto River Basin (Lower-Mondego).

Keywords: Conservation of soil, torrential correction, erosion, Pranto river basin.

* O texto deste artigo corresponde à comunicação apresentada ao VII Encontro Nacional de Riscos e I Forum ISCIA, tendo sido submetido para revisão em 07-05-2013, e aceite para publicação em 13-09-2013.

Este artigo é parte integrante da Revista Territorium, n. $020,2013,{ }^{\circ}$ Riscos, ISBN: 0872- 8941. 


\section{Introdução}

Como é conhecido, o fenómeno que designamos por erosão hídrica implica o escavamento das rochas, preferencialmente brandas, o transporte da carga sólida arrancada a essas rochas e a sua posterior deposição, com eventual sedimentação, ou seja, envolve um conjunto de processos naturais, cuja atuação pode ser acentuada devido a intervenções antrópicas inadequadas. Frequentemente, quando as consequências se agravam, há necessidade de realizar intervenções com o objetivo de minimizar os efeitos erosivos e de assegurar a manutenção dos sistemas hidráulicos fluviais em condições normais de funcionamento. Por outro lado, a conservação do solo deve ser encarada como uma prioridade e, por isso, considerada de forma a encontrar um nível de produção superior ao valor da perda de solo, para que, teoricamente, se permita a sua regeneração natural (M. Ponce Álvares e M. Pimenta, 1998).

De facto, as partículas do solo são erosionadas e, posteriormente, depositadas onde a energia do escoamento disponível passa a ser insuficiente para o transporte. Deste modo, a perda do solo por erosão hídrica está dependente da precipitação, do tipo de solos, dos materiais rochosos, dos declives e da (in) existência e tipo de vegetação. Ora, a erosão hídrica dos solos e a consequente produção de sedimentos tem sido objeto de preocupação crescente ao longo dos tempos, tanto em termos da gestão do uso do solo como da água, a qual é mais sentida em espaços geográficos com predominância de uma certa variabilidade de temperaturas e precipitações, como é o caso do clima mediterrâneo, agravando-se nas situações em que o solo é escasso e pouco profundo.

Assim, no século passado, recorreu-se à chamada correção torrencial, com o objetivo de mitigar este processo, tendo sido realizadas, em todo o País, grandes obras de engenharia e tomadas outras medidas de prevenção e defesa do solo contra a erosão. A bacia hidrográfica do rio Mondego foi uma das primeiras a sofrer obras de intervenção, tanto em termos dos canais fluviais como a nível das vertentes, destacando-se os rios Pranto ou de Carnide e Arunca, dois dos mais importantes afluentes do setor jusante da Bacia, o Baixo Mondego, localizando-se na margem esquerda do rio Mondego (fig. 1).

Deste modo, o objetivo que preside à elaboração deste trabalho consiste, nesta primeira fase, na identificação das obras de correção torrencial que foram realizadas na bacia hidrográfica do rio Pranto, durante a primeira metade do século $X X$, bem como na descrição da metodologia utilizada na sua construção, especificando as técnicas e os materiais usados, ou seja, pretende-se dar conhecer com algum pormenor os projetos que foram desenvolvidos. Numa segunda fase, o estudo irá incidir

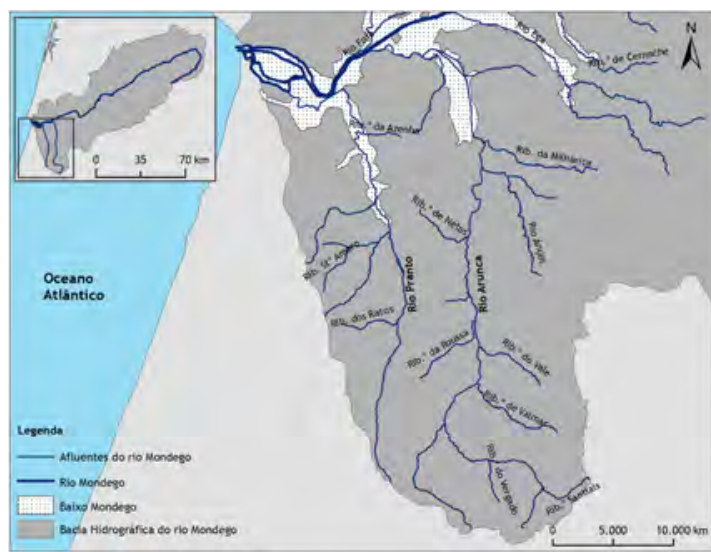

Fig. 1 - Esboço de localização dos rios Arunca e Pranto no Baixo Mondego. Em cartela, bacia hidrográfica do rio Mondego. Fonte dos dados: Agência Portuguesa do Ambiente.

sobre o estado atual dessas construções, por forma a avaliar os benefícios resultantes da sua construção e a verificar, mais de meio século após essa construção, se ainda cumprem a função para que foram projetadas.

A metodologia usada para a realização deste trabalho consistiu, nesta primeira fase, na consulta de bibliografia específica referente ao tema abordado, designadamente dos arquivos correspondentes a projetos, registos fotográficos e cartografia da localização das obras relativos à correção torrencial realizada na bacia hidrográfica do Rio Mondego, no período compreendido entre 1941 e 1977, existentes no Instituto de Conservação da Natureza e das Florestas. A partir destes documentos foi criada uma base de dados na ferramenta Excel, sintetizando as obras de correção torrencial projetadas. Depois, com recurso aos Sistemas de Informação Geográfica, foi feita cartografia, em ArcGis 9.3, com a representação espacial das linhas de água intervencionadas no rio Pranto, o que possibilitou localizar as ribeiras mais afetadas e que mereceram a elaboração de projetos de correção durante esse período (fig. 2).

\section{0 combate à erosão do solo em Portugal}

No nosso tipo de clima, a água é, sem dúvida, o mais importante agente erosivo. Por isso, quando uma vertente é atingida pela água da chuva, se, porventura, ela for composta por materiais facilmente desagregáveis e se encontrar desprovida de revestimento vegetal, fica sujeita a um trabalho de escavamento, que pode causar vários prejuízos. Dependendo do declive da vertente, a intensificação do processo erosivo tem início, quase sempre, junto às linhas de água e, à medida que vai remontando cabeceiras, em presença de condições adequadas, como sejam declives com alguma expressão, rochas desagregadas, pouco permeáveis e com pouco ou nenhum revestimento florestal, abrem-se sulcos, que tendem a ampliar-se até produzirem longos e profundos barrancos, como foi observado na área de estudo (M. Gallo, 1930). 


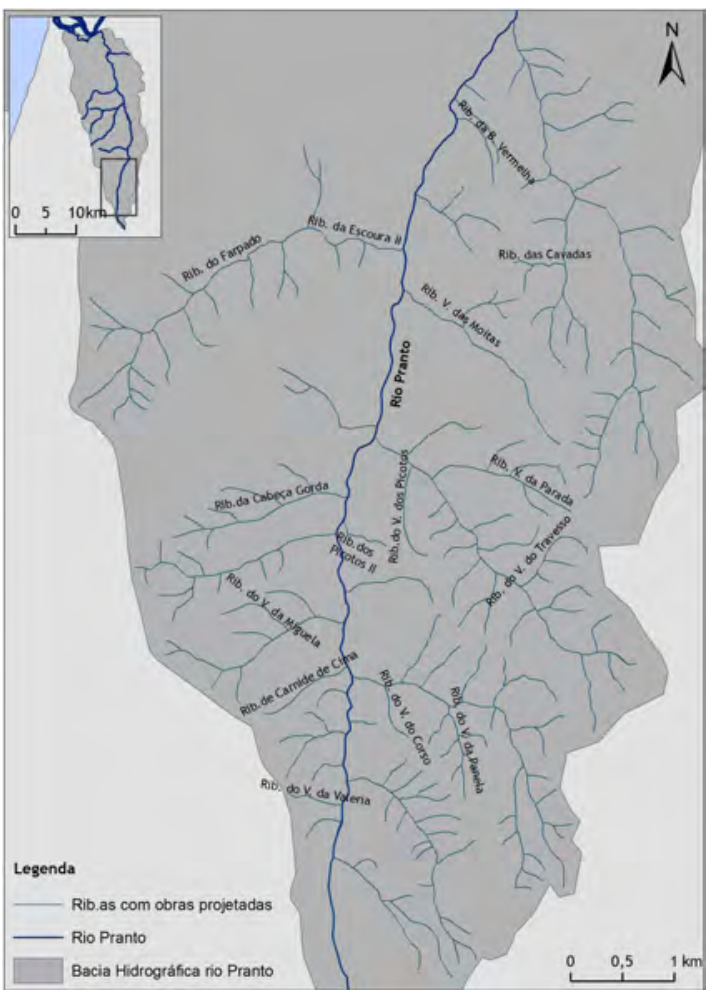

Fig. 2 - Cursos de água, afluentes do rio Pranto, que por motivos avançado processo de erosão hídrica foram submetidos à projeção de obras de correção torrencial.

Fonte dos dados: Altas do Ambiente e Instituto de Conservação da Natureza e das Florestas.

Ora, a erosão hídrica dos solos tem início com a precipitação. A distribuição e continuidade da ação da chuva no solo origina a desintegração dos agregados em partículas mais pequenas, principalmente quando atingidas por impacte direto das gotas da chuva. A quantidade de solo desestruturado aumenta com a intensidade da precipitação. Os impactes das gotas propiciam um adensamento natural do solo, ocasionando a sua impermeabilidade e, consequentemente reduzindo a capacidade de infiltração da água (M. SILVA et al., 1995). Este processo conduz a uma situação de escorrência superficial, ocorrendo, assim, erosão quando os valores de precipitação excedem a capacidade de infiltração do solo, verificando-se o transporte de partículas do solo, que seguem, geralmente as linhas de água, sendo depositadas somente quando a velocidade da água for mais reduzida e perder a capacidade de transporte, o que ocorre, na maior parte dos casos, nas secções jusante dos rios (F. PRUSKI, 2000).

O processo erosivo apresenta ainda outros fatores bastante importantes e que vão determinar a dimensão do processo em termos da sua intensidade e dos maiores ou menores impactes. São eles o relevo, onde a erosão é agravada na presença de grandes declives, mesmo em áreas de mais baixa altitude, especialmente quando a composição geológica é constituída por materiais freáveis e, também, pela pobreza das pastagens naturais, que, em Portugal, especialmente durante os séculos XIX e XX, eram consumidas principalmente pelas espécies caprinas e ovinas.

Para além destes fatores, a existência e o tipo de revestimento florestal, bem como as intervenções antrópicas, assumem grande importância na intensificação e aceleração do processo de erosão hídrica, principalmente devido ao uso de técnicas e práticas de cultivo inadequadas, à desflorestação, aos pastoreios excessivos, às queimadas e aos incêndios florestais e, por vezes, aos desvios dos cursos de água, com o objetivo de melhor aproveitar a terra. Todas estas intervenções conduzem a uma alteração das condições hidrológicas, acabando por estreitar os cursos, o que vai facilitar uma maior erosão, ou levam a marginalização e o abandono das terras ou, ainda, a construir em locais inapropriados, originando alguma instabilidade localizada.

Como consequência da atuação prolongada destes processos conta-se, por um lado, a degradação e o empobrecimento dos solos com aptidão florestal e, por outra parte, o assoreamento dos campos agrícolas situados a jusante, o que origina enormes prejuízos económicos, sobretudo naquela época em que a terra era a principal forma de subsistência para grande parte das famílias. Com efeito, a instabilidade de diversas linhas de água, a grande carga sólida que afluía aos rios e o seu posterior assoreamento a jusante, criavam condições para, nas épocas mais pluviosas, ocorrerem inundações que, além de danificarem as culturas, muitas vezes deixavam os campos soterrados num mar de areias. Uma completa alteração na paisagem.

Para obviar a esta situação, foi criado um programa específico, que se especifica a continuação.

\section{Enquadramento legislativo}

Para pôr cobro aos elevados prejuízos económicos e sociais que a dimensão do fenómeno de erosão hídrica representava em Portugal, foram criados os Serviços de Hidráulica Florestal, através do Decreto de 24 de dezembro de 1901, atribuindo-lhes a responsabilidade de realizarem "[...] o revestimento e as obras de arte dos perímetros demarcados com o fim de corrigir ou regularizar o regime dos cursos de água e a conservação e a policia das obras de arte, sementeiras e plantações, enquanto não forem entregues ao serviço de exploração" (M. Gallo, 1960).

Anos mais tarde, em 1930, surgiu a Junta Autónoma de Obras de Hidráulica Agrícola com o objetivo de planear e construir obras de fomento hidroagrícola, onde estavam incluídas barragens, sistemas de regularização fluvial e perímetros de rega. A Junta do Rio Mondego surgiu com este enquadramento e, em 1936, apresentou um Plano para o melhoramento de 10 000ha de terras correspondentes aos campos de 
Coimbra, o qual compreendia um conjunto de obras de hidráulica fluvial que incluíam obras de melhoramento do rio e obras destinadas à defesa contra cheias e contra o assoreamento (INAG, 2002). Anos mais tarde, em 1950, a Junta Autónoma de Obras de Hidráulica Agrícola foi integrada na Direção Geral dos Serviços Hidráulicos (INAG, 2002).

Entretanto, em 1941, sob a responsabilidade da então Direção dos Serviços Florestais e Aquícolas, que tinham sido criados em 1919, sob a tutela governativa do Ministério da Agricultura, deu-se início a uma fase de construção de grandes obras de engenharia florestal em Portugal sob responsabilidade do Gabinete de Estudos e Obras de Correção Torrencial, organismo a quem estava confinada a missão de Defesa, Conservação e Valorização do Solo Nacional, nomeadamente com obras de correção torrencial e realização de um Plano de Povoamento Florestal, em 1938, com vista à arborização das serras do interior, como consta do Decreto-Lei n. ${ }^{\circ} 254 / 2009$ de 24 de Setembro.

Depois, em 1954, a Direção Geral dos Serviços de Hidráulica recebeu uma diretiva, por parte do então Ministro das Obras Públicas, em que se afirmava "entre os aproveitamentos hidráulicos encarados com mais empenho figura o da bacia do rio Mondego" e justificava pelo elevado interesse desta bacia dos pontos de vista da produção de energia elétrica e da rega e, ainda, pela existência de problemas importantes de regularização do leito do rio.

Com efeito, o solo é um dos recursos mais importantes da Biosfera e do Património Natural para toda a Humanidade, pois é "o principal sistema de suporte da vida e do bem-estar humano. Fornece o substrato para as raízes, retém água o tempo suficiente para esta ser utilizada pelas plantas e fixa nutrientes essenciais para a vida " (J. BriLha e A. SÁ, 2007, p. 2). Por outro lado, a sua degradação traduz-se numa perda de utilidade para os seres vivos, devido à sua modificação ( $R$. WAsson, 1987), representando um verdadeiro problema que, não sendo de agora, é bastante atual, com grandes impactes e prejuízos ambientais, económicos e sociais, que originam, em consequência, um entrave ao desenvolvimento dos países (LAL, 1998).

O fenómeno erosivo através de exemplos na bacia hidrográfica do rio Pranto

Em Portugal, tal como aconteceu noutros países de todo o Mundo, a grande preocupação na preservação do solo surgiu depois da tomada de consciência da sua importância económica, social e paisagística, em resultado de graves problemas de erosão e degradação, causados por atividades agrícolas neles desenvolvidas, com profundas implicações sociais, ambientais e com enormes prejuízos económicos, sendo vários os fatores que contribuíram para a dimensão que o processo de erosão hídrica assumia por todo o País, como era o caso de diversos ribeiros afluentes ao rio Pranto (fot.s 1 e 2).

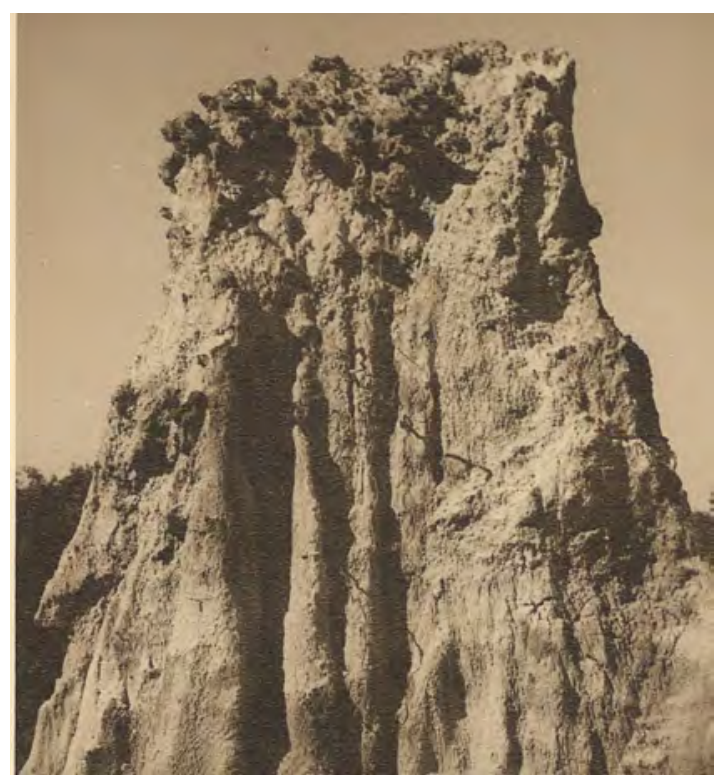

Fot. 1 - Pirâmide de erosão localizada na margem esquerda do ribeiro do Vale da Parada, afluente do rio Pranto, em abril de 1946.

Fonte: Arquivo fotográfico do Instituto de Conservação da Natureza e das Florestas).

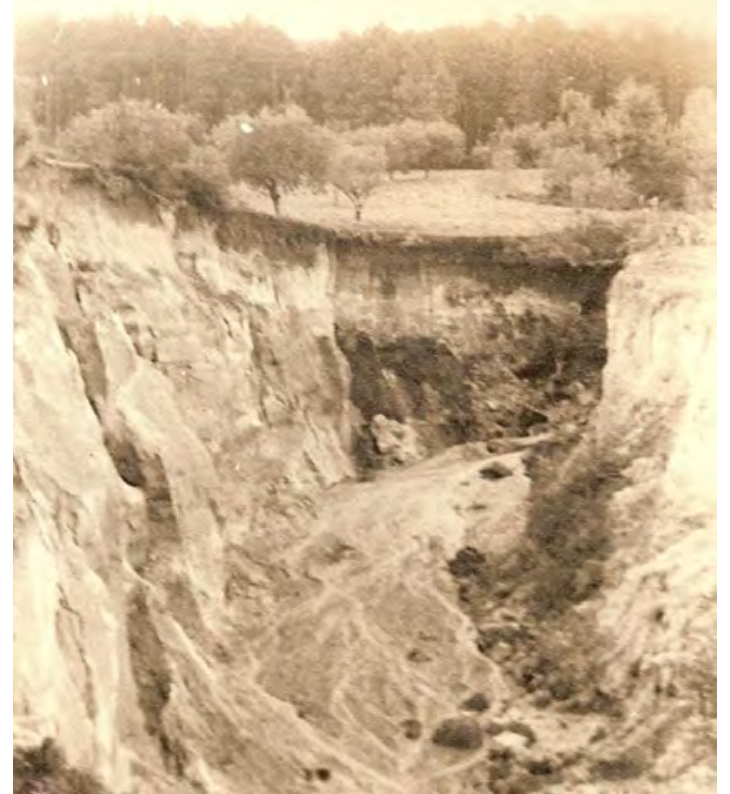

Fot. 2 - Aspeto do fenómeno erosivo no ribeiro da Valeira, afluente do rio Pranto, com destruição de campo agrícola, em novembro de 1959. Fonte: Arquivo fotográfico do Instituto de Conservação da Natureza e das Florestas.

De facto, eram enormes os prejuízos originados pela ação das torrentes, verificando-se danos tanto nos locais de escavamento, como, a jusante, naqueles onde decorria a deposição. Na primeira situação contamse, a título de exemplo, os consideráveis volumes de materiais de pequenas dimensões que foram arrancados, e em consequência deu-se a perda de matéria orgânica, 
degradação estrutural e empobrecimento do solo, compactação da superfície do solo, redução da infiltração da água, redução da alimentação dos aquíferos, aumento da fração grosseira do solo, formação de regos, sulcos e barrancos, desenraizamento de plantas e redução da produtividade do solo (fot.s 3 e 4).

No segundo caso, quando os materiais erosionados foram depositados em campos de cultura, ocasionaram a esterilidade desses campos, e quando o foram em canais fluviais, levaram ao assoreamento dos rios (fot. 5), à alteração da secção dos cursos de água e à obstrução de redes de drenagem, dando origem a cheias e inundações mais violentas, ao soterramento de infraestruturas e contribuindo para a eutrofização e poluição dos cursos de água.

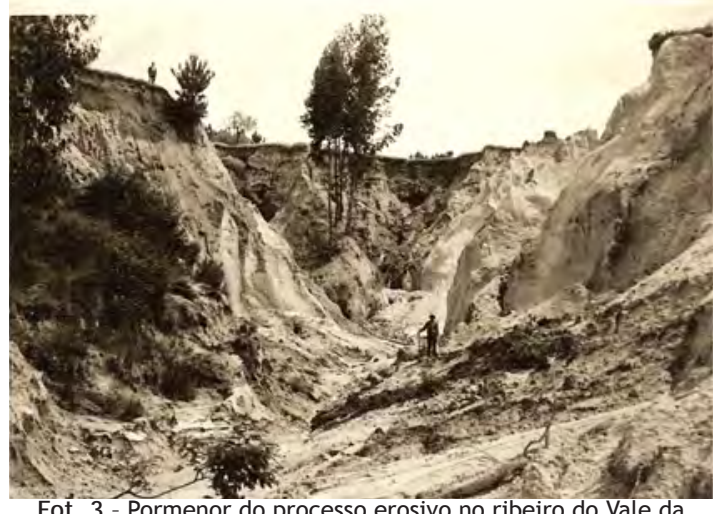

Fot. 3 - Pormenor do processo erosivo no ribeiro do Vale da Parada, afluente do rio Pranto, em junho de 1959.

Fonte: Arquivo fotográfico do Instituto de Conservação da Natureza e das Florestas.

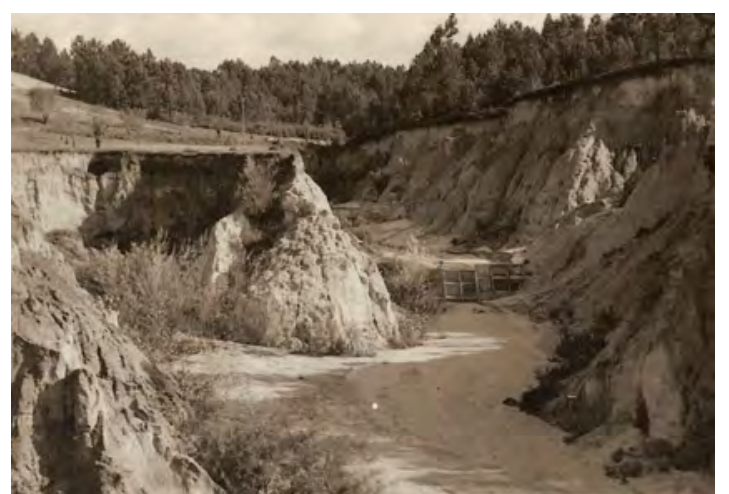

Fot. 4 - Aspeto do resultado do fenómeno erosivo no ribeiro do Vale da Parada, em outubro de 1964.

Fonte: Arquivo fotográfico do Instituto de Conservação da Natureza e das Florestas.

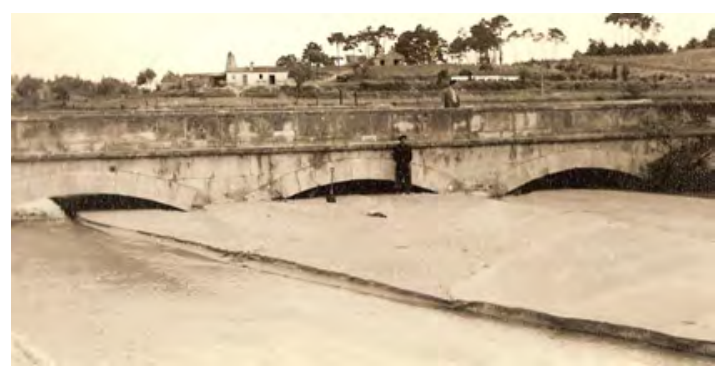

Fot. 5 - Estado de avançado assoreamento do rio Pranto, junto à ponte da Palha, em junho de 1959.

Fonte: Arquivo fotográfico do Instituto de Conservação da Natureza e das Florestas.

\section{A Correção Torrencial em Portugal}

A grande intensidade que o processo de erosão hídrica apresentava em Portugal, nos finais do século XIX e início do século XX, levou a que o País embarcasse numa espécie de "movimento" que já se vinha a verificar noutros países da Europa (Roxo, 2001), levando a cabo o desenvolvimento de uma série de estudos e trabalhos no âmbito da correção torrencial na tentativa de travar/ mitigar o problema da erosão dos solos e consequências daí resultantes.

Os trabalhos de correção torrencial foram todos eles baseados na utilização de vegetação, visto que o revestimento vegetal impede o início ou a continuidade da atividade erosiva das torrentes. Contudo, para introduzir a vegetação onde se verificava erosão dos cursos de água era necessário, em primeiro lugar, fixar o solo, protegendo-se, assim, as culturas e as povoações que se encontram nos vales. Para o consolidar, converteram-se as torrentes em ribeiros, com leitos definidos sobre os cones de dejeção, o que favoreceu o aproveitamento de campos produtivos que, até então, estavam impedidos de serem utilizados, e regularizou-se o regime dos rios, afastando os danos materiais provocados pelas inundações, o que só foi possível através de obras de engenharia (J. MоTA, 1973), pois, apenas a floresta, restituída ao seu lugar normal na bacia de receção, é capaz de produzir a extinção de torrentes, conservando assim o efeito benéfico dos trabalhos de correção, que acabam por ser os meios que a floresta aproveita para se implantar solidamente (Ruy MAYER, 1941).

As obras de correção torrencial apresentaram-se, pois, como a solução para estes problemas. Com este trabalho procederemos à divulgação de algumas dessas obras e, num próximo estudo, pretendemos verificar se foram eficazes e, por conseguinte, se minimizaram os problemas da acentuada erosão hídrica da bacia do rio Pranto.

Métodos de Correção Torrencial aplicados em Portugal

A execução dos trabalhos de correção torrencial seguiu, em Portugal, uma lógica organizacional que dependeu, do tipo de torrentes existentes, o qual condicionou a sequência dos trabalhos que foram levados a cabo para que se atingi-se um bom resultado no combate à erosão hídrica (TABELA I). Deste modo, foi seguida a classificação do tipo de torrentes proposta por Louis Prosper DEMONTZEY, citado por M. Gallo (1919-1930), que considerava três tipos de torrentes: de escavação, de transporte e mistas.

Assim, quando ocorriam torrentes de transporte, considerava-seque deveriamserseguidas as duas primeiras alíneas por, neste caso, serem as mais importantes. Por sua vez, quando se tratava de torrentes de escavação eram tidas em conta as duas últimas alíneas $\left(3 .^{\mathrm{a}}\right.$ e $\left.4 .^{\mathrm{a}}\right)$. 
Finalmente, numa situação de torrentes mistas, isto é, aquelas que incorporam as de escavação bem como as de transporte, deveriam ser tomados os procedimentos que dessem origem à estabilização da bacia de recepção e do canal de escoamento, pelo que, nestes casos, a ordem de trabalhos passava pelo cumprimento, na íntegra, das quatro fases de trabalho (TABELA I).

Depois de formada uma torrente, para que seja possível a sua extinção, torna-se necessário efetuar obras no canal abdutor, dito de escoamento, pois é aqui que existem os maiores declives e onde as águas têm maior poder de escavação e de transporte. Este canal é constituído, quase sempre, por uma garganta inicial, apertada e de margens muito inclinadas, que as águas vão consecutivamente aprofundando e aumentando em largura. Ora, para que o talvegue não seja escavado e para que não se verifique o transporte de materiais é necessário reduzir a velocidade de escoamento da água e dar ao leito um declive tal que as águas não ultrapassem a sua velocidade limite de transporte. Deste modo, diminuindo a velocidade das águas, reduzse, consequentemente, o poder de transporte que, para além de um certo valor, poderá cessar completamente, dando-se início à estabilização do leito até ser atingido o perfil de equilíbrio (J. MотA, 1973), impossibilitando, assim, que a água continue o seu trabalho de escavar e aprofundar o leito.

As técnicas de correção torrencial que foram utilizadas para a obtenção de perfis de equilíbrio, passaram pela construção de sebes, faxinagens e barragens dispostas de forma transversal ao longo do talvegue dos rios, ficando o leito cortado por uma série de degraus, com a finalidade de diminuir a velocidade das águas. Na realização das obras de correção era importante ter em conta o perfil de equilíbrio e o perfil de compensação porque, de outra forma, as mesmas poderiam arriscarse a serem escavadas pela base, acabando por não haver uma correção eficaz e por colocar em risco toda a estrutura edificada, o que se tornaria mais dispendioso em termos monetários.

Depois desta fase, dava-se início à correção das vertentes e das bacias de receção com recurso à arborização, por forma a controlar a erosão, ou seja, foram efetuados trabalhos de fixação por meio de vegetação, tanto nas vertentes do canal de escoamento como na própria bacia de receção. Este método tinha como finalidade possibilitar uma completa estabilidade não apenas das linhas de água, mas também das vertentes que as marginam. Com este objetivo foram utilizadas espécies cujo sistema radicular apresentasse um grande desenvolvimento.

Para além da arborização dos locais mais afetados, foram também utilizadas outras técnicas complementares dos trabalhos de correção torrencial, mais económicas, mas que apresentam um contributo importante no controlo da instabilidade de margens e vertentes, como foi o caso da construção de sebes mortas ou vivas.

De facto, com o contributo do revestimento vegetal foi possível fixar o terreno com as raízes das plantas e aumentar a permeabilidade do solo, uma vez a vegetação retém, nas folhas, uma parte importante da água precipitada, ação que corresponde a uma certa correção torrencial, capaz de mitigar o processo de erosão hídrica.

\section{Construção de Barragens}

As barragens de correção torrencial foram uma das principais técnicas utilizadas para combater a erosão hídrica, apesar de essa não ser a sua única função, tendo sido construídas em cursos de água com regime torrencial (fot. 6).

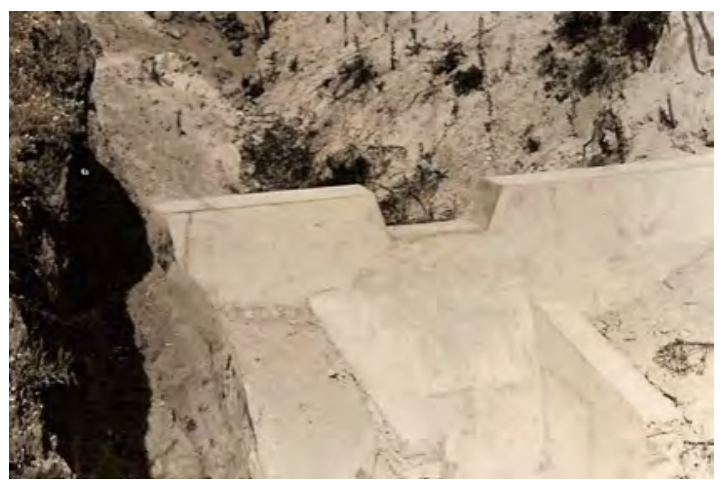

Fot. 6 - Exemplo de uma barragem de Alvenaria construída no ribeiro dos Picotos II, afluente do rio Pranto, no ano de 1968. Fonte: Arquivo fotográfico do Instituto de Conservação da Natureza e das Florestas.

Do ponto de vista da mitigação do fenómeno da erosão, a técnica das barragens apresenta diversas vantagens, pois, entre outros aspetos, potencia a

TABeLA I - Ordem de execução dos trabalhos de correção torrencial.

\begin{tabular}{|c|l|}
\hline $\begin{array}{c}\text { Ordem de } \\
\text { execução }\end{array}$ & \multicolumn{1}{c|}{ Trabalhos a executar } \\
\hline $1 .^{\circ}$ & Estudo e demarcação dos perímetros a arborizar ou a manter arborizados na bacia da linha de água. \\
\hline $2 .^{\circ}$ & Repovoamento de todos os terrenos instáveis abrangidos no perímetro. \\
\hline $3 .^{\circ}$ & Fixação dos terrenos instáveis por meio de trabalhos de correção. \\
\hline $4 .^{\circ}$ & Repovoamento dos terrenos instáveis, à medida que se vão realizando os trabalhos de engenharia \\
\hline
\end{tabular}


diminuição da velocidade de escoamento, retém e acumula sedimentos, permite suprimir a escavação do leito do rio/ribeiro no sentido longitudinal e o seu posterior alargamento, afasta a corrente dos taludes laterais, suporta aterros formados a montante das margens instáveis e cria condições para a reinstalação de vegetação. Com a construção sucessiva de barragens suavizam-se os declives (fot.7), permitindo assim alcançar-se um certo perfil de equilíbrio (J. МотA 1973).

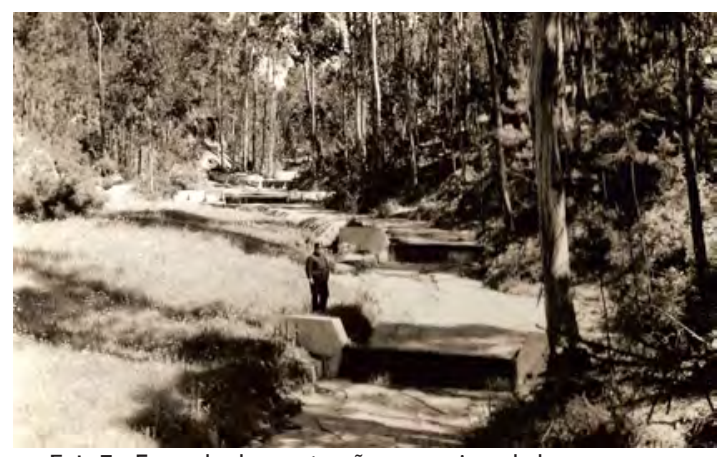

Fot. 7 - Exemplo de construções sucessivas de barragens, no ribeiro do Vale do Travesso, afluente do rio Pranto, no ano de 1960. Fonte: Arquivo fotográfico do Instituto de Conservação da Natureza e das Florestas.

Todavia, a construção de pequenas barragens não é assim tão linear e simples, pois, quando os cursos de água apresentam já um processo avançado de erosão hídrica, verificam-se alguns entraves à sua construção. A título de exemplo menciona-se uma situação em que as margens de um curso de água se apresentavam com cota pouco elevada em relação ao seu talvegue, não havendo, desta forma, altura suficiente de margem para construir a barragem. Uma outra situação decorreu quando o talvegue apresentava um declive acentuado e uma largura pequena, o que tornava necessário, para o mesmo caudal, o aumento da secção de vazão, o que, em largura, não era possível e, em altura, era inconveniente, acabando por ser difícil atingir o perfil de equilíbrio nestas circunstâncias.

Em ambas as situações foi necessário efetuar a proteção do talvegue para impedir a erosão o que se conseguiu, a título de exemplo, pela construção de um canalete (fot. 8) que, com maior declive do que o perfil de equilíbrio e pequena seção, permitia a passagem de um grande caudal. $\mathrm{O}$ canalete reduzia-se a um simples calcetamento do talvegue quando o caudal era pequeno.

Relativamente à escolha do local para a implantação das barragens, tinham-se em conta diversos aspetos, de entre os quais se salienta a importância de, sempre que possível, ficarem assentes em terrenos firmes, numa perspetiva mais economizadora dos recursos a utilizar. Além disso, preferiam-se os locais cuja seção transversal fosse estreita, especialmente com a finalidade de reduzir o volume de materiais a empregar, sempre que não se previssem riscos da água escavar os taludes e, consequentemente, comprometer a segurança da construção.

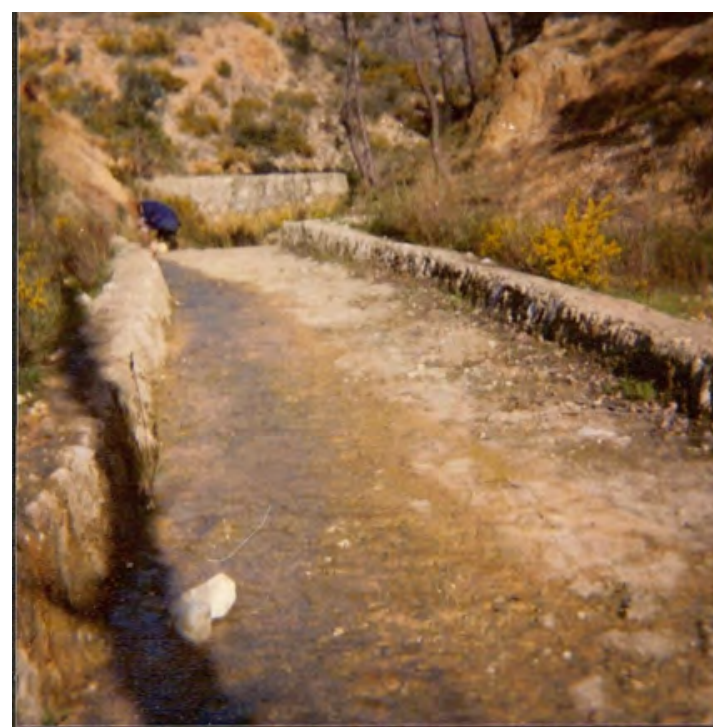

Fot. 8 - Canalete para a condução das águas, também utilizado como caminho para veículos de tração animal. Fonte: José MoTA, 1973.

Um outro aspeto relevante e que era equacionado nas estratégias de correção torrencial está relacionado com o facto de se considerar sempre mais vantajoso reduzir o número de barragens, aumentando-lhes a altura, pois, a médio ou longo prazo, esta prática aumenta a superfície dos taludes laterais protegidos e o volume de materiais sólidos retidos, tornando-se necessárias menos fundações (M. Gallo, 1929-30).

Normalmente, as barragens foram construídas na perpendicular ao eixo da corrente mas, quando necessário, foi possível a sua construção em traços curvilíneos. Uma barragem em secção transversal pode apresentar uma forma trapezoidal ou pentagonal. A primeira foi a mais utilizada.

Em suma, a construção de barragens foi o método mais utilizado na correção de torrentes, pois contribui imediatamente para a diminuição do declive do fundo do leito do rio, o que favorece a diminuição dos efeitos erosivos e a deposição de material, contribuindo-se, desta forma, para se alcançar o designado perfil de equilíbrio.

\section{Constituição das barragens}

Uma barragem é composta por vários elementos, em que cada um deles tem a sua importância para o bom funcionamento e estabilidade da obra, bem como para que seja atingido o seu principal objetivo: a colmatação do processo de erosão hídrica. Assim, estas pequenas barragens apresentam características comuns, podendo ser analisadas em separado e distinguidas cada uma das partes que as constituem, descrição que consta dos diferentes projetos de correção torrencial elaborados pelos engenheiros envolvidos nas obras de correção: $M$. Gallo, J. de Almeida Eliseu, f. Ramos, A. Fernandes, V. Albuquerque Quintanilha, J. Caldas, H. de Magalhães e Fernando Palma. 
0 rebordo superior da barragem, designado por coroamento, pode apresentar-se, em relação à sua disposição, quer na horizontal, quer com alguma inclinação, podendo, neste caso, subir para jusante ou para montante, ou, ainda, da boca para a extremidade das asas. Este rebordo superior comporta a seção de vazão (fig. 3), que era construída de modo a permitir não só a passagem das águas, mas também a dirigi-las para a parte mais resistente do talvegue. No cálculo das dimensões do descarregador tinha-se em consideração o caudal líquido e o caudal sólido. A secção de vazão apresenta normalmente uma forma simétrica, que é utilizada para condições normais de escoamento, ou seja, quando este se processa pela zona central da barragem. Nestes casos, as bocas têm a forma de um trapézio, com a base maior para cima ou, então, a forma de um retângulo. Por vezes, a secção apresenta uma forma assimétrica, a qual foi utilizada quando se pretendeu lançar a água para um flanco rochoso, apresentando neste caso figuras geométricas não definidas (J. MoTA, 1973).

As partes laterais da barragem que flanqueiam a boca denominam-se asas e devem ficar bem encastradas nas margens, de forma a evitar qualquer infiltração que possa interferir com a segurança da obra. As barragens comportam, ainda, as soleiras, que vão proteger a base do corpo da barragem do poder de escavação da água, pelo que é construída onde a água precipita depois de passar pela boca, imediatamente a jusante desta, devendo ser calculada tendo em conta a queda da água e os materiais transportados. Para além da soleira, os muros de ala devem estar bem encastrados no corpo da barragem, principalmente quando as mesmas não são ladeadas por muros longitudinais que impeçam que a água corroa os taludes marginais. Por vezes, quando determinadas condições de declive motivam uma maior velocidade das águas e, por conseguinte, maior capacidade de transporte de mais sedimentos e mais pesados, torna-se mais conveniente construir uma barragem e uma soleira ligadas às já existentes em vez de construir novas que se designam de contra - barragem (fig. 4) e contra soleira (fig. 3). Estas obras complementares têm como finalidade criar um lençol de água sobre a soleira, de modo a amortecer a violência da queda das águas e dos materiais, construindo-se um dente, na extremidade da soleira, com uma altura que ronda 40 a 50 centímetros.

Tipologia de Barragens utilizadas na correção torrencial

Os tipos de barragens construídas especialmente durante a primeira metade do século $\mathrm{XX}$ estão relacionadas com os diferentes materiais com que foram feitas. Desta forma, classificam-se em (Mário Santos Gallo , 1929-30):

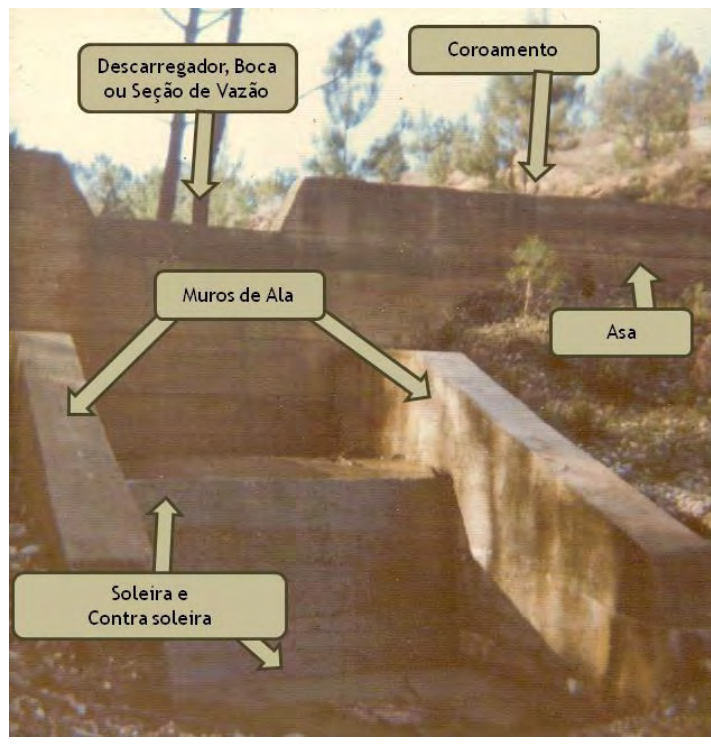

Fig. 3 - Constituintes principais das barragens de correção torrencial. Fonte: Adaptado de J. MOTA, 1973.

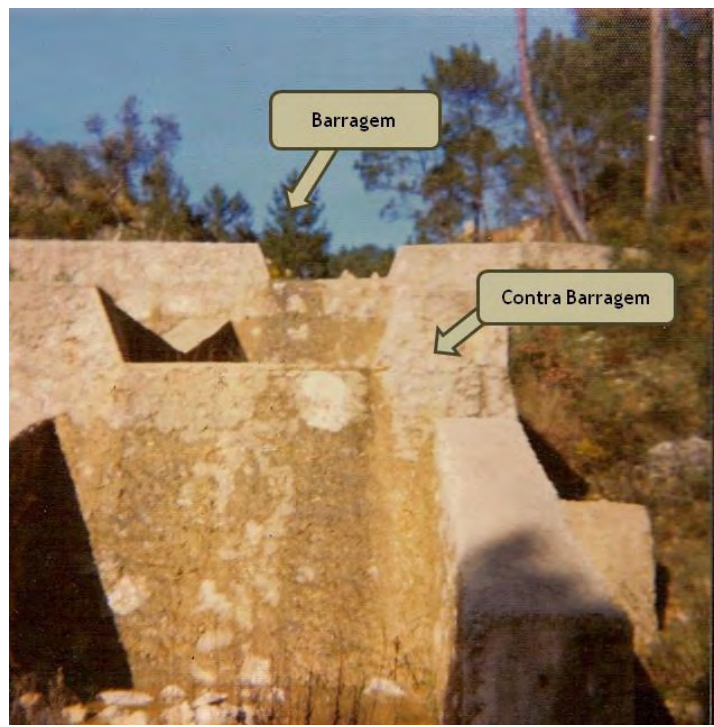

Fig. 4 - Exemplo de uma barragem e contra barragem de correção torrencial. Fonte: Adaptado de J. МотA, 1973.

- Barragens de Terra;

- Barragens de Gaviões (do tipo “gabbioni”);

- Barragens de Madeira;

- Barragens de Alvenaria;

- Barragens de Betão Armado;

- Barragens de Laje;

Barragens de Terra

Consideram-se barragens de terra, aquelas em que a estrutura é fundamentalmente constituída por solo ou enrocamento. O solo é, portanto, utilizado como material de construção neste tipo de obras, sendo extraído da 
área de implantação da barragem, o que as torna, sob o ponto de vista ambiental menos agressivas do que as barragens de betão. Por vezes, o corpo destas barragens apresenta uma estrutura complexa, constituída por diversos materiais que cumprem funções distintas. Basicamente, o corpo da barragem é constituído essencialmente por um núcleo em material argiloso, dois maciços estabilizadores situados a montante e a jusante do núcleo, cujo objetivo é o de garantir a estabilidade do corpo, um conjunto de drenos e filtros, que visam dotar a barragem de zonas de escoamento da água que circula por infiltração e reduzir os riscos de criar fendas, uma proteção do talude de montante, que está sob o efeito direto da ação das águas e uma proteção de talude a jusante, contra a ação da água e do vento (F. QUINTAS, 2002).

Estas barragens de terra são mais económicas, mas nem todos os locais reúnem as condições necessárias para o seu emprego. Por um lado, exigem que no terreno haja uma certa percentagem de argila e que os materiais se apresentem com certo grau de humidade, o que na prática é difícil de se verificar, havendo, por isso, necessidade de calibrar e misturar as terras para que se obtenha material com suficiente compacidade para a construção. Por outro lado, devido à largura do leito, uma vez que se obtêm melhores resultados em locais com maior largura, dado que não há um risco elevado de corrosão das asas e é mais fácil fixar o leito. Contudo, estas barragens têm uma necessidade de vigilância constante, o que as tornas dispendiosas em termos de recursos humanos para a sua manutenção.

\section{Barragens do tipo "gabbioni"}

As barragens do tipo "gabbioni” são bastante utilizadas na Itália, onde tiveram a sua origem, sendo muito úteis para a proteção das margens dos rios e dos taludes. São constituídas por caixas de rede de arame de ferro galvanizado que é preenchido por pedras colhidas no leito da torrente e, é com estas caixas que, posteriormente, são construídos os muros das barragens. Como aspeto positivo apresenta-se o fator económico. 0 aspeto menos positivo tem a ver com o arame, pois, mesmo que bem galvanizado, quando em contacto com a água, acaba por se degradar. Apesar disso, em grande parte dos casos, quando esta situação se verifica já as pedras se encontram cimentadas e com consistência suficiente para resistirem à erosão. Todavia, caso não se verifique a coesão das pedras e haja uma destruição do arame, as reparações devem ser feitas de imediato, acabando por se tornar num processo mais dispendioso. Este tipo de barragem apenas pode ser aplicado em determinadas circunstâncias, pois, nos casos em que o leito apresenta um certo declive e um grande volume de águas, é muito complicado aplicar este tipo de barragem, sob pena de serem destruídas ou arrastadas.
Barragens de Madeira

Este tipo de barragem é construído em áreas onde se pode obter madeira a curta distância das obras o que as torna em construções mais económicas do que as anteriores.

São empregues para pequenas correções aproveitando deste modo a resistência e elasticidade da madeira (fot. 9). Foram, ainda, realizadas construções onde a madeira se utilizava para formar compartimentos para preencher com pedra e/ou cascalho. Contudo, um dos seus inconvenientes tem a ver com a curta longevidade destas obras, uma vez que quando a madeira está, alternadamente, em contato com a água e a seco, sofre uma degradação rápida, pelo que a sua utilização deixou de ser frequente, caindo mesmo em desuso.

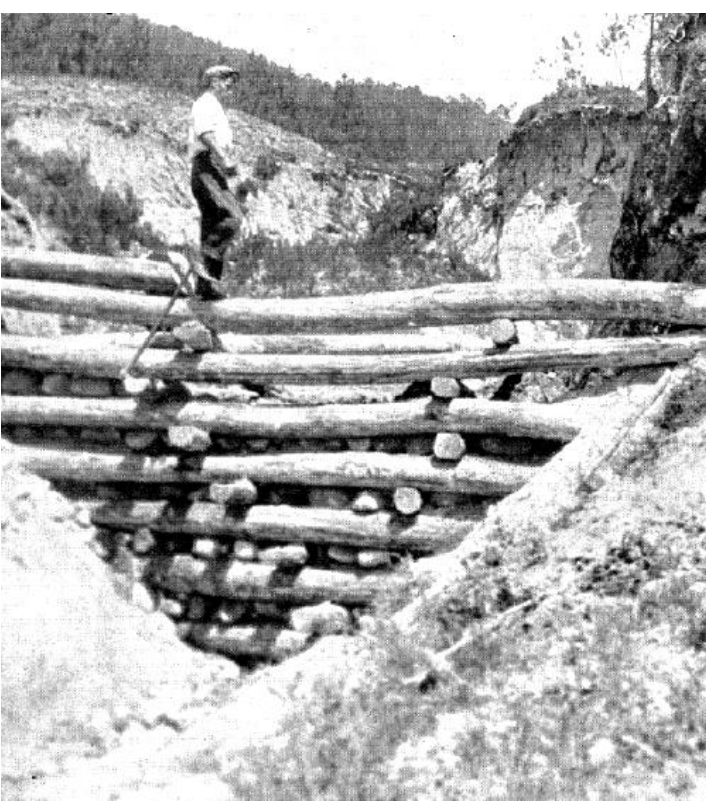

Fot. 9 - Exemplo de uma barragem de madeira e calhau rolado, em construção no ribeiro do Vale do Olharo. Fonte: Ruy MEYER, 1941.

Barragens de Alvenaria

As barragens de alvenaria são a melhor opção quando os caudais são fracos na época seca, o transporte de materiais é à base de areias, os leitos se apresentam com pequena largura e grandes declives e com os taludes laterais de grandes alturas e inclinações. Nestes casos é mais vantajoso, do ponto de vista da correção torrencial, que a sua construção se faça com uma altura considerável, dado que estas barragens resistem pelo seu próprio peso à impulsão das terras. Contudo, atendendo a que o volume de materiais empregados neste tipo de barragem em altura cresce em tal proporção, torna-se economicamente mais compensatório construir várias barragens de dimensão mais pequena (M. Gallo, 1942).

Dependendo do modo como a matéria-prima é utilizada, este tipo de barragem subdivide-se nos seguintes: 
- Alvenaria de Pedra Solta;

Alvenaria Argamassada

- Alvenaria Mista;

- Alvenaria Argamassada.

Alvenaria de Pedra Solta

Este tipo de barragem tem aplicação numa situação em que, no local da obra, haja disponibilidade de materiais de dimensões e peso suficiente para darem estabilidade à obra, a qual não deverá exceder 4 metros de altura e só serão de utilizar quando não houver uma tendência para ocorrerem grandes impulsões dos aterros formados a montante.

Em Portugal este tipo foi muito construído (fot.10) especialmente na correção de ravinas de pequenas dimensões, com resultados satisfatórios. No entanto, estas barragens caíram em desuso devido à necessidade de mão-de-obra especializada, o que encarecia em demasia o custo das obras, dado o elevado montante dos salários.

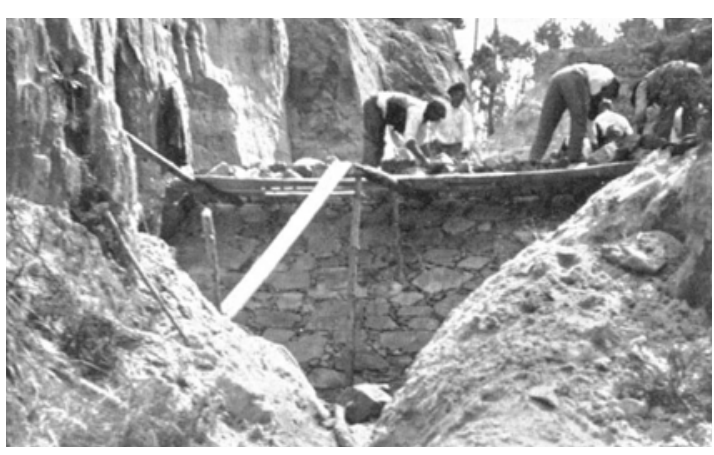

Fot. 10 - Barragem de pedra solta, em fase de construção. Fonte: Ruy MEYER, 1941.

\section{Alvenaria Mista}

Para a construção deste tipo de barragens utiliza-se um método que consiste na formação de um núcleo de pedra solta que é revestido, nos parâmetros e no coroamento, por alvenaria argamassada (fot. 11). Como são pouco resistentes, não há uma compensação económica na sua construção, sendo por isso pouco difundidas em Portugal.

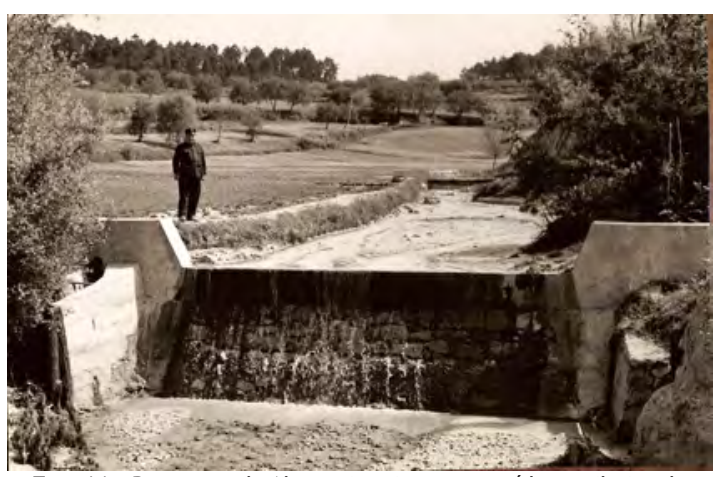

Fot. 11 - Barragem de Alvenaria mista construída no ribeiro do Vale da Parada, afluente do rio Pranto, em abril de 1960.

Fonte: Arquivo fotográfico do Instituto de Conservação da Natureza e das Florestas.
As barragens do tipo alvenaria argamassada são as mais utilizadas em Portugal (fot.s 12 e 13) devido à sua grande resistência e menor espessura, podendo construir-se com recurso a argamassa de cal hidráulica ou a cimento, sendo tidos em consideração diversos critérios nessa construção (TABELA II).

\section{Barragens de Betão Armado}

Este tipo de barragem apenas foi utilizado quando, nos locais das obras, não se disponha de pedra de alvenaria apropriada ou o seu transporte fosse difícil e dispendioso, e, em contrapartida, existisse areia em quantidade suficiente para a construção (fot.14). Tinham o inconveniente de necessitar de cofragens para a edificação das mesmas.

\section{Barragens de Laje}

Do ponto de vista económico as barragens de alvenaria eram muito dispendiosas, especialmente devido ao transporte, para os locais das obras, da pedra e dos materiais necessários à sua construção, pelo que se pensou utilizar outro tipo de barragens. Inicialmente, adotaram-se os "gabbioni", mas o calhau rolado não era suficiente, pelo que se passou a recorrer às barragens de cimento armado, mas estas tinham outro inconveniente, pois necessitavam de pessoal especializado, o que não era facilmente conseguido, acabando por ser discutível a sua relativa vantagem económica. Foi neste contexto que apareceu um novo tipo de barragens, as de Laje, concebidas pelo engenheiro Mário dos Santos Gallo que, com elas, desejava suprimir as dificuldades de construção das anteriores barragens e, além disso, que pudessem oferecer alguma vantagem económica.

Estas barragens foram, então, construídas utilizando lajes independentes, de pequenas dimensões (fot. 15), exigindo fraca armadura, com a vantagem de poder ser moldada junto ao local de construção das obras e de se utilizarem os mesmos moldes para uma grande quantidade de peças. O agrupamento das lajes era efetuado em fiadas transversais e, desde que a fiada superior fosse colocada fora do limite do ângulo do talude natural do terreno, poderiam aumentar o número de fiadas, na medida em que cada uma delas apenas tinha de suportar a impulsão das terras equivalentes à sua altura (M. GALLO, 1942).

Nas primeiras barragens deste tipo, as lajes, com cerca de $70 \mathrm{~cm}$ de altura por 1,30 m de comprimento, eram ancoradas ao terreno por peças de cimento armado. Foram calculadas para resistir à pressão das terras, considerando os seus extremos simplesmente apoiados 
TABELA II - Critérios de construção de barragens de alvenaria argamassada.

\begin{tabular}{|c|c|}
\hline \multicolumn{2}{|r|}{ Critérios de construção } \\
\hline 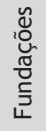 & $\begin{array}{l}\text { Sempre que possível devem atingir terreno firme. Quando não é possível deve então efetuar-se uma "sapata" de largura } \\
\text { superior à da barragem para aumentar a estabilidade da mesma ou apoiar-se a soleira em estacaria. }\end{array}$ \\
\hline 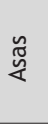 & $\begin{array}{l}\text { Asseguram o encastramento da barragem nos taludes laterais e sempre que elas sejam pouco consistentes convém } \\
\text { prolonga-las em distância. Se o talude se apresenta rochoso e firme, deve ser talhado de modo a obter-se uma superfície } \\
\text { de apoio irregular para facilitar a ligação com a alvenaria e se surgem degraus estas devem ter inclinações de } 5 \text { a } 10 \% \\
\text { para montante. }\end{array}$ \\
\hline$\underset{\circlearrowright}{\mathscr{0}}$ & $\begin{array}{l}\text { As suas dimensões devem permitir a passagem dos caudais correspondentes às cheias máximas, tendo em atenção que } \\
\text { por vezes os materiais equivalem a uma percentagem elevada do caudal liquido. Se não se conseguir calcular o caudal } \\
\text { máximo com razoável aproximação dá-se à boca uma área igual à de uma seção da torrente situada a montante, que se } \\
\text { saiba ter dimensões bastante grandes para comportar o caudal máximo. }\end{array}$ \\
\hline 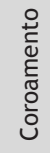 & $\begin{array}{l}\text { Deve ser robusto, para poder resistir ao choque dos blocos que a torrente arrasta e à ação de desgaste que as enxurradas } \\
\text { produzem quando existe transporte de areias e calhaus angulosos. }\end{array}$ \\
\hline 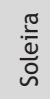 & $\begin{array}{l}\text { Proteger o fundo do leito, a jusante da barragem, por meio de uma soleira que não só impede a escavação como } \\
\text { comporta o choque dos carrejos e atenua a velocidade da água. As soleiras são construídas com alvenarias hidráulicas } \\
\text { (soleiras rígidas) ou alvenaria solta, recorrendo a grandes blocos. }\end{array}$ \\
\hline
\end{tabular}

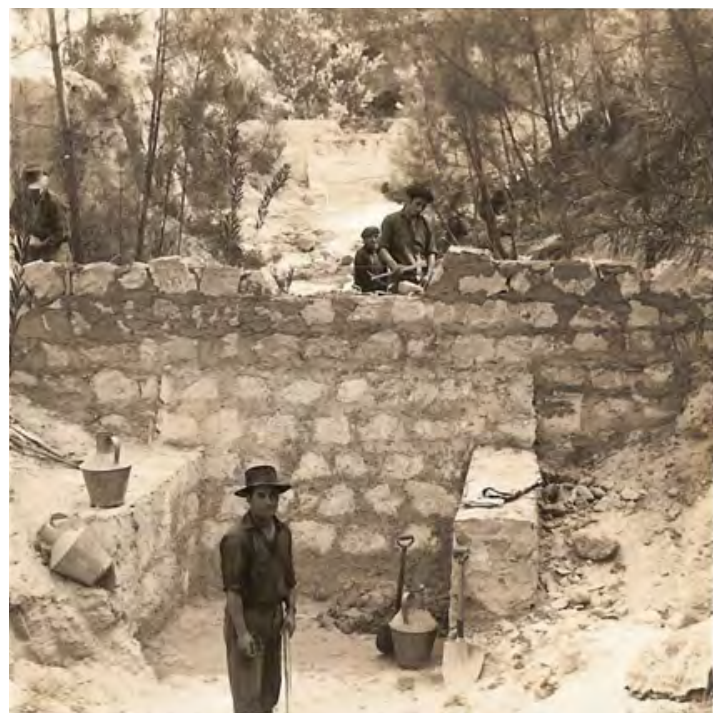

Fot. 12 - Barragem de alvenaria argamassada em construção no ribeiro das cavadas, afluente do rio Pranto, em agosto de 1969. Fonte: Arquivo fotográfico do ICNF.

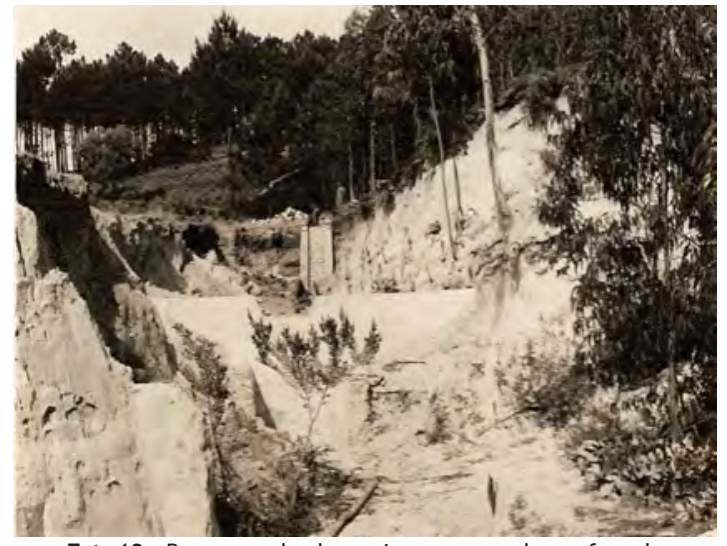

Fot. 13 - Barragem de alvenaria argamassada em fase de construção no ribeiro dos Picotos II, afluente do rio Pranto, em agosto de 1968. Fonte: Arquivo fotográfico do ICNF.

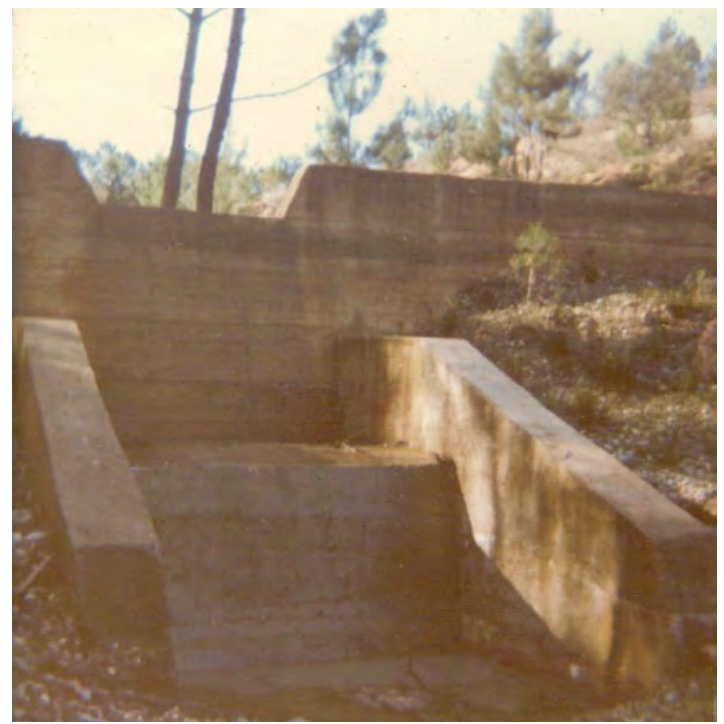

Fot. 14 - Barragem de Betão com soleira e contra soleira. Fonte: J. MотA, 1973.

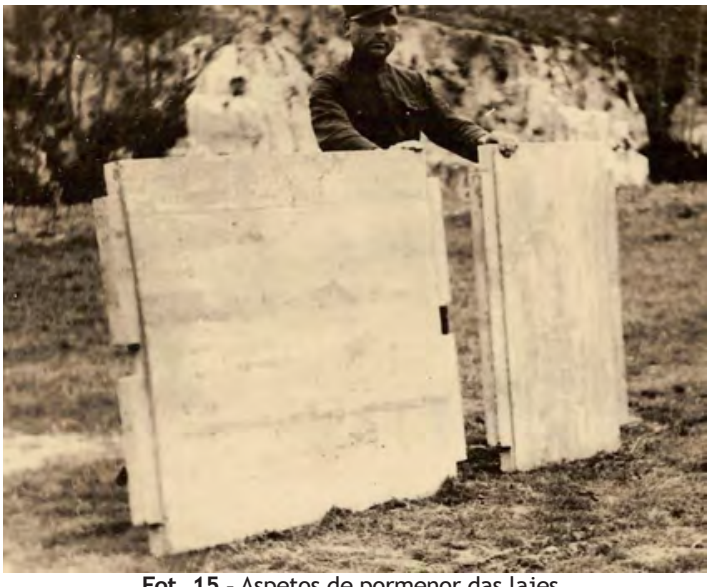

Fot. 15 - Aspetos de pormenor das lajes. Fonte:M. Gallo, 1942 
e a sapata da âncora fixa fora do limite do ângulo do talude natural do terreno (fot. 16).

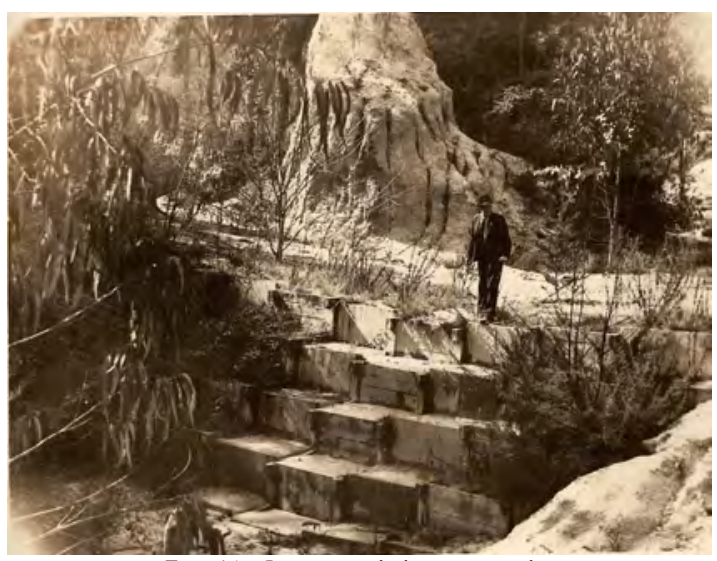

Fot. 16 - Barragem de laje ancorada. Fonte:M. Gallo, 1942.

O descarregador era formado por todo o comprimento da barragem, mas o nível entre as duas lajes continuas decrescia $10 \mathrm{~cm}$ da periferia para o centro, de modo a que a laje central ficasse mais baixa do que as restantes obrigando, assim, o caudal normal a passar sempre no centro da barragem. Nas lajes centrais o espaço entre as diferentes fiadas era calcetado e as juntas das pedras levavam argamassa para impedir que a queda da água escavasse o terreno.

Contudo, este primeiro sistema não era perfeito, pois a barragem não tinha um descarregador definido, além de que, por vezes, surgiam dificuldades na desmoldagem da âncora, o que não permitia a utilização do mesmo molde muitas vezes. Por isso, em vez de ancoradas, as barragens passaram a ser escoradas (fot.s 17 e 18).

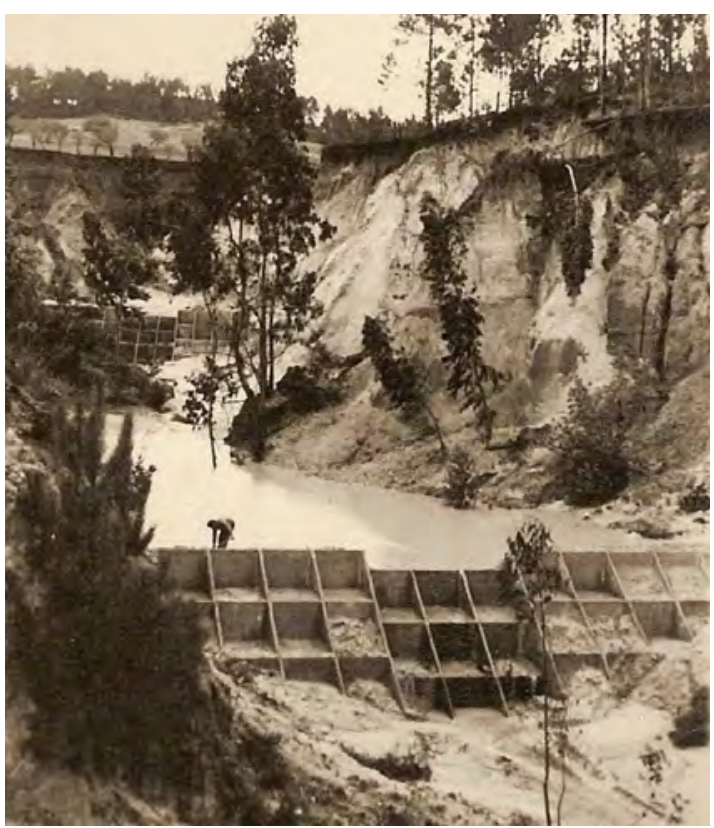

Fot. 17 - Barragem de laje escorada construída no ribeiro do Vale da Parada, afluente do rio Pranto, em 1959.

Fonte: Arquivo fotográfico do Instituto de Conservação da Natureza e das Florestas.

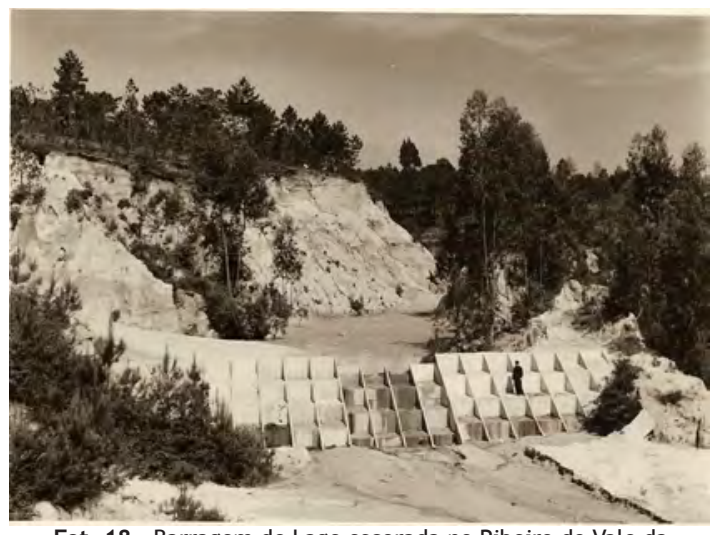

Fot. 18 - Barragem de Lage escorada no Ribeiro do Vale da Miguela, afluente do rio Pranto, em 1960.

Fonte: Arquivo fotográfico do Instituto de Conservação da Natureza e das Florestas.

Por outro lado, a altura da barragem foi, nestes casos, aumentada para $1 \mathrm{~m}$ e, para a sua armadura, passou a utilizar-se material distendido em vez de rede de arame. O comprimento máximo manteve-se em cerca de $1,30 \mathrm{~m}$. Por sua vez, o descarregador passou a ter $50 \mathrm{~cm}$ de altura e uma largura variável (ex. 0,50m, 1,20m, 1,80m...). 0 espaço entre as duas fiadas de lajes consecutivas passou a ser revestido com alvenaria, ao longo do descarregador, para evitar que a água escavasse o terreno. Por último, as escoras utilizadas tinham uma forma paralelogrâmica. Inicialmente eram constituídas por esquadros de betão armado, que se apoiavam no terreno por intermédio de um maciço de alvenaria, sendo necessário juntar também pequenos muros de alvenaria para proteção lateral das bocas. No entanto, a dificuldade de obtenção do varão de ferro para a armadura dos esquadros e por forma a reduzir o uso de alvenaria, levou a que as escoras passassem a ser construídas em placas de betão armadas com metal despendido e a sua ligação com as lajes era feita através de dentes moldados. Assim, as escoras passaram a ficar encastradas no terreno, na parte jusante, e apoiadas posteriormente numa estaca de madeira cravada no terreno (fot. 19).

\section{Sebes e faxinagens}

As sebes e faxinagens são técnicas de engenharia natural muito simples, económicas e eficazes na correção torrencial e na mitigação do fenómeno erosivo, permitindo o sucesso de outras intervenções de médio e longo prazo na recuperação das áreas erosionadas (Guiomar e Fernandes, 2009), como é o caso da construção de barragens. De facto, estas técnicas são de baixo custo, essencialmente graças aos materiais utilizados e à facilidade de recolha de material. Além disso, são de realização simples, não necessitando de mão-de-obra especializada, e apresentam uma importante eficácia estabilizante. Por último, após o seu desenvolvimento, poderão funcionar como fornecedor de material vivo, que poderá funcionar noutras intervenções. 

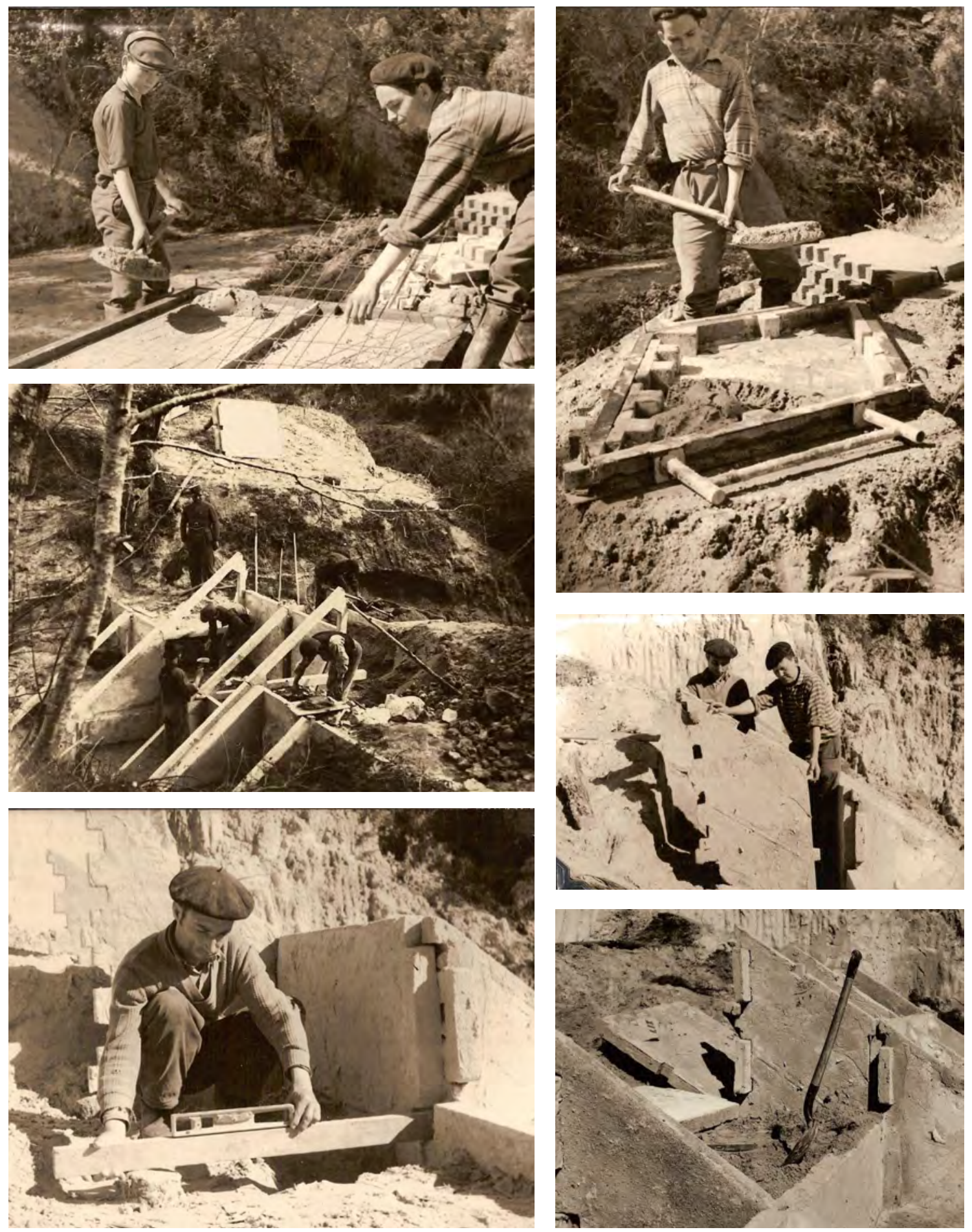

Fot. 19 - Detalhes da montagem de uma barragem de laje escorada, encastrada no terreno Fonte: M. GaLlo, 1942.

No que concerne às sebes, são construídas por estacas introduzidas no terreno e dispostas na perpendicular relativamente ao eixo da linha de água, ficando afastadas entre si em cerca de 30 a $40 \mathrm{~cm}$ (J. MотA, 1973). As estacas são entrelaçadas por varas ou ramos com a finalidade de formar uma malha de tal forma apertada que impeça a passagem de sedimentos e outros materiais. As sebes podem ser mortas ou consideradas vivas, quando são constituídas por estacas verdes, provenientes de espécies que enraízam depressa como é o caso dos salgueiros.

A construção das faxinagens é semelhante à das sebes, pois também são introduzidas estacas nas linhas de água, de modo perpendicular ao eixo da corrente, embora não sejam feitas com ramarias, pois, em vez disso, 
são amarradas com feixes, colocados posteriormente às estacas, sendo apoiados nestas. As estacas são de madeira e devem ser colocadas com uma distância entre si que pode variar entre $30 \mathrm{~cm}$ e $1 \mathrm{~m}$ (J. МотA, 1973).

\section{Técnicas Complementares de Correção}

As técnicas complementares mais usadas para consolidação e correção das torrentes consistem nos revestimentos longitudinais, que têm por objetivo aumentar a resistência do leito e das margens. Estes trabalhos surgem também como alternativa à construção de barragens, quando estas são difíceis de aplicar ou se tornam métodos mais dispendiosos, como sucede no caso de alguns setores dos leitos com declive mais acentuado. Para fazer face a este tipo de situações foram utilizadas diversas técnicas que surgem como alternativas no combate à erosão hídrica, sendo cada uma delas aplicada consoante a situação em causa.

Deste modo, nos leitos dos rios que apresentavam uma topografia irregular, com declives acentuados, uma das técnicas utilizadas passava pela aplicação de canaletes (fot. 8), ou seja, pela construção de pequenos canais empedrados. 0 uso desta técnica permitia aumentar a resistência do leito da torrente e, deste modo, atravessar terrenos facilmente escaváveis sem os escavar. Nessa época, outra função dos canaletes foi a sua utilização como caminho de veículos de tração animal sendo que, nesta circunstância, o material de construção era pedra e argamassa.

Por vezes, nas barragens, ocorria a manifestação de erosão lateral, a qual podia comprometer a própria estabilidade da obra e a sua finalidade principal, acabando por se perder todo o investimento feito, o que acarretaria vários prejuízos económicos. Nestas condições recorreu-se à construção de paredes de alvenaria, designadas por esporões ou espigões, que serviam para proteger essas obras, conferindo-lhes alguma segurança e longevidade. Estes esporões eram constituídos por muros profundamente introduzidos nas margens que se pretendiam defender, podendo apresentar ângulos variáveis.

Quando o processo de erosão já se encontrava numa fase avançada, muitas vezes verificava-se a formação de barrancos que, dependendo do seu estado de desenvolvimento, podiam apresentar uma grande diferença de nível, no talude. 0 método utilizado para proteger o talude contra a erosão, de modo a conferirthe alguma estabilidade era a construção de entradas de água (fot.s 20, 21 e 22). Eram constituídas por uma conduta, a céu aberto e de grande inclinação, que terminava numa soleira e num pequeno dente, cuja função seria permitir a formação de uma almofada de água para amortecer a queda das águas provenientes da bacia de receção. A técnica utilizada em situações de declive bastante acentuado passava pela construção de sucessivos degraus na entrada de água.

Para que a água fosse canalizada/dirigida para a entrada de água foram abertas valas na bacia de receção, garantindo assim o escoamento da água para o local desejado. Estas valas requeriam manutenção no que toca à sua limpeza, de forma a permanecer eficaz na sua ação.

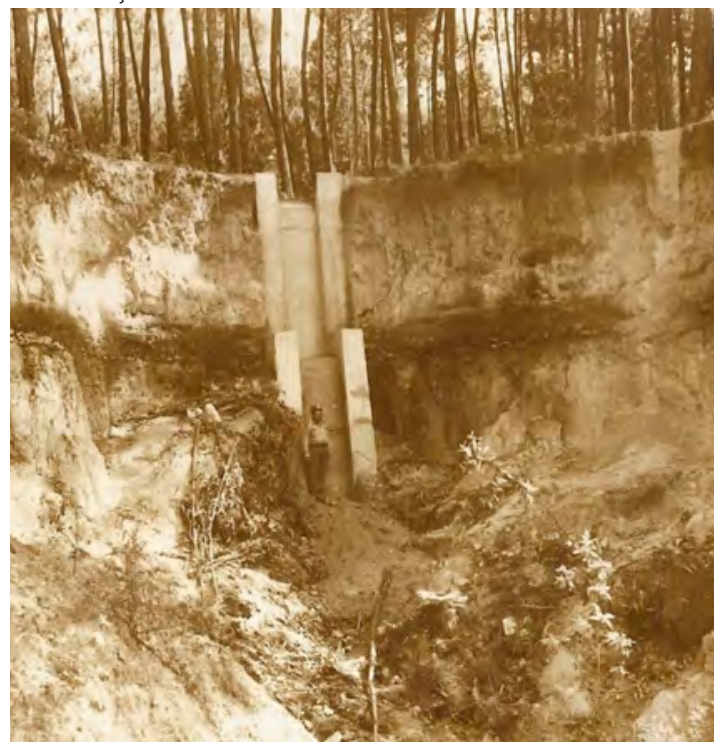

Fot. 20 - Entrada de água no ribeiro da Barreira Vermelha, afluente do rio Pranto, em 1969. Fonte: Arquivo fotográfico do Instituto de Conservação da Natureza e das Florestas.

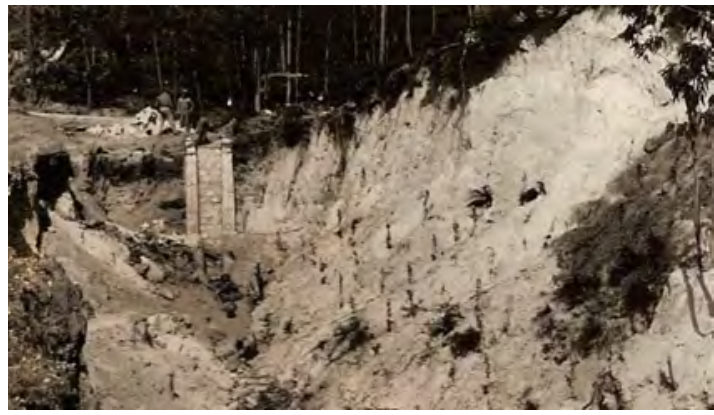

Fot. 21 - Entrada de água em construção no ribeiro do Vale dos Picotos, afluente do rio Pranto, em 1968.

Fonte: Arquivo fotográfico do Instituto de Conservação da Natureza e das Florestas.
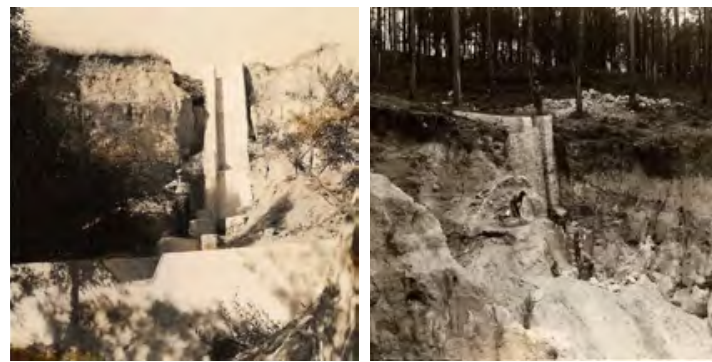

Fot. 22 - Construção de entradas de água em ribeiros afluentes do rio Pranto. À esquerda, no ribeiro do Vale da Parada, em agosto de 1969, e à direita, no ribeiro do Vale do Corso, em 1970.

Fonte: Arquivo fotográfico do Instituto de Conservação da Natureza e das Florestas. 
Contudo, a construção de barragens, canaletes e entradas de água não eram suficientes para mitigar o processo de erosão hídrica, pelo que falta referenciar um dos principais aspetos, no que diz respeito à consolidação de vertentes, visto que só após esse trabalho se poderão obter resultados satisfatórios no controlo de erosão e na correção de torrentes. Com este objetivo, fez-se a consolidação de vertentes, através de revestimento vegetal ou por consolidação natural. Do mesmo modo, o sopé das vertentes deve estar bem defendido contra a erosão, pelo que se efetuaram trabalhos, tais como a construção de valas, que seguiam as linhas de maior declive.

Por último, ocorria outra situação que exigia trabalhos de correção complementares, nomeadamente quando uma torrente se encontrava em contacto com o sopé de uma vertente instável e originava o escavamento da base desta e, devido ao trabalho de sapa, a posterior deslocação de materiais suprajacentes que eram arrastados pela água. A este fenómeno era dado o nome de "quebradas por descalçamento" (M. Gallo, 1929-30) e o combate era feito através do desvio da corrente da vertente através da construção de espigões ou com revestimento, na vertente, de estacarias ou muros de alvenaria (fot. 23).

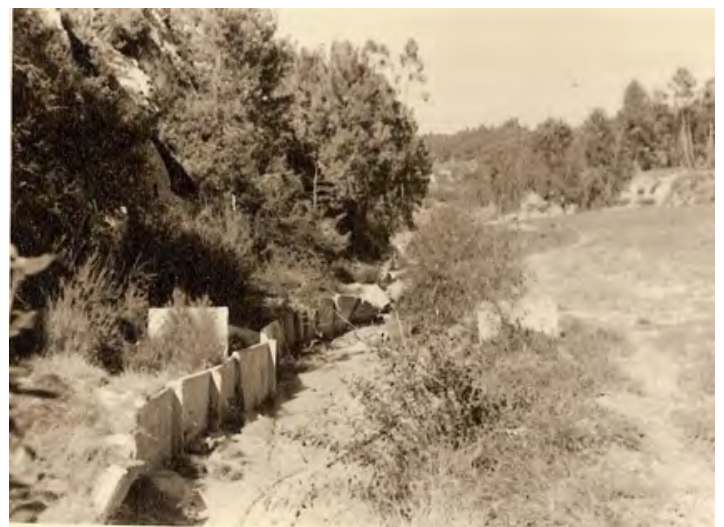

Fot. 23 - Placas de proteção das margens do ribeiro do Vale da Panela, afluente do rio Pranto, em 1959.

Fonte: Arquivo fotográfico do Instituto de Conservação da Natureza e das Florestas.

Importância da vegetação para a correção torrencial

Quando o transporte de materiais sólidos é proveniente de vertentes que circundam a linha de água, como por exemplo no caso das torrentes de transporte, as barragens servem para reter esses materiais que só cessarão de afluir à linha de água depois de fixar o solo na área correspondente à bacia de receção, o que só é possível com a arborização das vertentes mais erosionadas e com declive mais acentuado e, ao mesmo tempo, pela prática de uma agricultura racional e sustentável dos restantes campos. Contudo, a arborização, nos taludes dos barrancos ou das torrentes, não pode manter-se sem a prévia estabilização do leito, através de obras de correção que, impedindo a erosão de fundo, evitam o desmoronamento dos taludes. Deste modo, sem o revestimento de vegetação (fot. 24), não é possível atingir uma estabilização do processo erosivo e da correção de torrentes, pois, num período relativamente curto, a erosão retoma a sua ação colocando em causa a própria segurança das obras. Assim, percebese que existe uma dependência entre estes processos de correção, ou seja, as obras e a arborização, sendo por esta razão que a arborização era iniciada antes do término das obras de engenharia.

Neste sentido, verificou-se que era indispensável proceder à arborização, para conter os fenómenos erosivos, tendo sido, por isso, submetidas a regime/ revestimento florestal as faixas de proteção marginais, quer em taludes, quer em aterros privados e, ainda, em barrancos, situados a montante e a jusante das barragens.

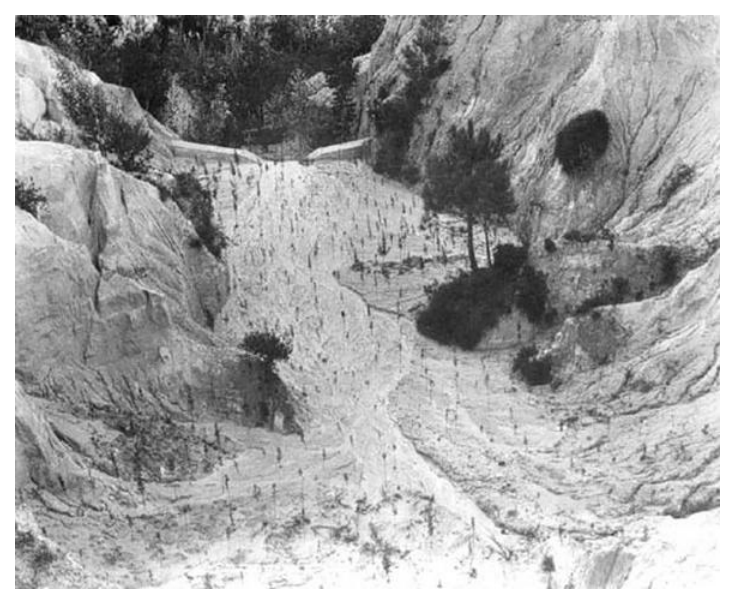

Fot. 24 - Revestimento florestal dos aterros afetados pelo processo de erosão. Fonte: Arquivo fotográfico do Instituto de Conservação da Natureza e das Florestas.

As áreas que foram submetidas a regime florestal, por serem distintas no que respeita aos locais de implementação, obedeciam a diferentes critérios quanto à largura das faixas de proteção e ao tipo de espécie a plantar. Assim, nos terrenos de cultura agrícola, foi fixada uma largura de 2 metros, para as faixas de proteção, onde se deviam plantar espécies que não prejudicassem essas culturas, quer pelo desenvolvimento radicular, quer pelo efeito de sombra a que pudessem dar origem. Por sua vez, em culturas florestais a largura das faixas subia para 10 metros ou 5 metros. Por último, também estava previsto arborizar os aterros das barragens, embora deixando o leito do ribeiro livre no alinhamento das bocas, por forma a permitir o livre escoamento das águas.

Relativamente às espécies a plantar, segundo o DecretoLei n. ${ }^{\circ} 28039$, de 14 de Setembro de 1937, era proibida a plantação ou sementeira de eucaliptos, acácias da espécie denominada dealbata, vulgarmente conhecida por acácia mimosa, e de ailantos, a menos de 20 metros de terrenos cultivados e a menos de 30 metros de 
nascentes, terras de cultura de regadio, muros e prédios urbanos, salvo algumas exceções referidas no mesmo artigo. Assim as espécies utilizadas mais frequentemente nas faixas marginais contiguas a terrenos em cultura agrícola foram as seguintes:

\author{
- Salgueiro-branco (Salix alba L.); \\ - Salgueiro-Preto (Salix atrocinerea, Brot); \\ - Vimeiro-branco (Salix viminalis, L.); \\ $\checkmark$ Amieiro (Alnus glutinosa, L. ); \\ - Cana (Arundo donax, L. );
}

Por sua vez, nas faixas marginais de cultura florestal, as mais usadas foram:

\author{
$\checkmark$ Pinheiro-bravo (Pinus pinaster); \\ - Eucaliptos (Eucalyptus globulus); \\ - Cupressus (Cupressus spp. ); \\ - Acácia Mimosa (Acacia decurrens, var. delbata); \\ - Acácia austrália (Acacia melanoxylon R. Br. ); \\ 口 Freixo (Fraxinus angustifólia Vahl);
}

Já no leito dos cursos de água, taludes e barrancos marginais, bem como nos aterros das barragens as espécies mais utilizadas foram:

- Eucaliptos (Eucalyptus globulus);

- Acácias diversas (Acacia spp.);

- Cana (Arundo donax, L. );

- Salgueiros (Salix, spp);

口 Choupos (Populos spp.).

Este tarefa de arborização era considerada fundamental, ao ponto de nenhum trabalho de correção torrencial se poder considerar terminado senão após estarem devidamente arborizadas as áreas necessárias.

\section{Considerações finais}

A erosão hídrica constitui, em Portugal, um dos principais fatores de degradação da camada edáfica superficial. São inúmeros os fatores que têm contribuindo para a degradação dos solos onde se destacam: irregular distribuição da pluviosidade anual, orografia, natureza dos solos, desflorestação, ocorrência de incêndios florestais, práticas agrícolas danosas e práticas de pastoreio excessivas. Os efeitos desta degradação traduzem-se em enormes perdas, tanto em termos ambientais, como em aspetos socioeconómicos, sobretudo quando o escoamento superficial se organiza e desencadeia processos erosivos mais intensos (ravinas e barrancos). Nestes casos, as consequências abrangem áreas mais vastas e conduzem à manifestação de outros processos, tais como o assoreamento dos leitos, a degradação da qualidade da água, a ocorrência de inundações mais danosas, com prejuízos económicos consideráveis.

Quando, em Portugal, a subsistência do ser humano dependia essencialmente da terra, a pressão sobre o solo intensificou-se e o coberto vegetal foi bastante dizimado o que, em conjunto com a orografia e o regime irregular das precipitações, por vezes, muito intensas, promoveu a ocorrência de processos erosivos bastante ativos. Este cenário conduziu à necessidade de intervenções ao nível da recuperação do coberto vegetal e à implementação de obras de correção torrencial.

Assim, a partir da década de 40, do século XX, os trabalhos de defesa e conservação do solo adquiriram um notável impulso sendo inúmeras a obras de correção torrencial realizadas nas bacias hidrográficas mais afetadas em termos erosivos e que mais e maiores prejuízos económicos estavam a causar. A primeira bacia hidrográfica a sofrer obras sistemáticas de correção torrencial foi a do rio Liz (S. Fernandes e L. Lourenço, 2013), por apresentar uma extensão reduzida, sendo por isso uma considerada uma boa área de aplicação experimental. Depois, uma das bacias mais intervencionadas foi a do rio Mondego, em particular, nas sub-bacias dos rios Arunca e Pranto, sendo disso testemunho as numerosas obras de correção torrencial e o legado documental deixado relativamente aos projetos e aos registos fotográficos que têm bem patentes o esforço, empenho e dedicação emprestados a este projeto, na sequência da diretiva do então Ministro das Obras Públicas, enviada em 1954 à Direção Geral dos Serviços de Hidráulica de então, onde se afirmava que "entre os aproveitamentos hidráulicos encarados com mais empenho figura o da bacia do rio Mondego".

Deste modo, durante esse período foram criadas, desenvolvidas e aplicadas diversas técnicas de correção torrencial, de entre as quais se destacam as numerosas barragens, essencialmente de alvenaria e de lajes, a aplicação de sebes e faxinagens, bem como a construção de entradas de água, valas e canaletes e, ainda, as vastas áreas (re)arborizadas. A finalidade de todas estas práticas foi, sobretudo, obter a regularização dos leitos dos rios, de modo a aproximarem-se do seu perfil de equilíbrio, o que implicou a estabilização de vertentes, taludes e barrancos, para controlo da erosão hídrica, de que o rio Pranto foi tomado como exemplo.

Todas estas obras exigiram um trabalho exaustivo, acompanhado de muita técnica e precedido de estudo e conhecimento minucioso das áreas de intervenção bem como dos regimes dos rios, além de mão-de-obra especializada e de uma grande capacidade de inovação, que se traduziu na criação de novas técnicas de correção torrencial, simples e mais económicas. 
De forma singela, tentámos exemplificar algumas delas, tomando como exemplo o rio Pranto. Como objetivo futuro, pretendemos avaliar o estado atual das áreas intervencionadas nesta bacia hidrográfica, para averiguar os resultados dessas obras, bem como os seus impactes e as suas vantagens, designadamente em termos de mitigação do processo erosivo. Além disso, tendo em conta as alterações socioeconómicas entretanto ocorridas, verificar em que medida essas obras se mantêm atuais e saber se o que foi feito ainda hoje tem realmente interesse. Esse será, certamente, o próximo desafio que nos propomos investigar.

\section{Agradecimento}

Expressamos o nosso agradecimento ao Eng. ${ }^{\circ}$ João Pinho, enquanto Diretor da ex-Autoridade Florestal Nacional, por nos ter facilitado o acesso aos arquivos bem como a consulta dos diversos tipos de documentos neles existentes e, também, pelo incentivo que nos deu para a realização deste estudo sobre as obras de correção torrencial implementadas no Baixo Mondego.

Ao Eng. ${ }^{\circ}$ Rui Rosmaninho, de Coimbra, na qualidade de Técnico Responsável pela ex-Unidade de Gestão Florestal do Centro Litoral, e à Eng ${ }^{\text {a }}$. Rita Matos Gomes, de Leiria, enquanto Técnica Superior da ex-Autoridade Florestal Nacional, estamos gratos pelo apoio logístico concedido e, sobretudo, pela constante disponibilidade demonstrada ao longo de toda a investigação, primeiro nas instalações dos Serviços Florestais em Leiria e, depois, no Choupal, em Coimbra, durante a consulta dos materiais existentes em arquivo, cuja riqueza é inquestionável, de que tentámos dar uma pálida imagem nestas páginas.

\section{Referências Bibliográficas}

Álvares, Maria Teresa Ponce e Pimenta, Maria Teresa (1998) - "Erosão hídrica e transporte sólido em pequenas bacias hidrográficas". Atas do 4응 Congresso da Água, Associação Portuguesa de Recursos Hídricos, 9 p. http://www.aprh.pt/ congressoagua98/files/com/149.pdf (acedido pela última vez a 20 de Fevereiro de 2013);

AndRAdA, Eduardo de Campos (1982) - 80 anos de actividade na correcção torrencial, hidráulica florestal: 1901-1980. Direcção Geral das Florestas, Lisboa, 106p.;

Bernardino, Sofia e Lourenço, Luciano (2012) - “Obras de correção torrencial e controlo da erosão hídrica em Portugal. Exemplo da bacia hidrográfica do rio Mondego". Riscos e Segurança (Resumos). VII Encontro Nacional de Riscos e I Fórum sobre Riscos e Segurança, Aveiro, p. 36;
BRILHA, J. e SÁ, A. (2007) - “O solo - pele da Terra”. Prospeto relativo a um tema-chave do Ano Internacional do Planeta Terra 2007-2009, Planeta Terra Ciências da Terra para a sociedade: http:// yearofplanetearth.org/content/downloads/ portugal/brochura10_web.pdf (acedido pela última vez a 20 de Fevereiro de 2013);

DECRETO de 24 de dezembro de 1901, publicado em Diário do Governo n. ${ }^{\circ} 296$ de 31 de Dezembro. http: / / www.icnf.pt/portal/icnf/legisl/ legislacao/1901-1/decret-24dez1901 (acedido pela última vez a 20 de Fevereiro de 2013);

DECRETO-LEI n. ${ }^{\circ}$ 28039, de 14 de Setembro de 1937 http://www.icnf.pt/portal/icnf/legisl/ legislacao/1937/dl-28039-14set (acedido pela última vez a 20 de Fevereiro de 2013);

DECRETO-LEI n ${ }^{\circ} 254 / 2009$ de 24 de setembro de 2009: http://dre.pt/pdf1s/2009/09/18600/0682206848.pdf (acedido pela última vez a 20 de Fevereiro de 2013);

Fernandes, Sofia e Lourenço, Luciano (2013) - “A importância das obras de correção torrencial no controlo da erosão hídrica. Exemplos na bacia hidrográfica do rio Liz". Cadernos de Geografia, n. ${ }^{\circ} 32$, Departamento de Geografia da Faculdade de Letras da Universidade de Coimbra ;

FerrelRA, Carmen do Céu Gonçalves (1996) - Erosão hídrica em solos florestais: estudo em povoamentos de Pinus Pinaster e Eucalyptus Globulus em Macieira de Alcôba, Águeda. Dissertação de mestrado em Geografia Física, Universidade do Porto, Porto, 186 p.;

Fialho, José e Lourenço, Luciano (2007) - “O papel dos socalcos na erosão e deposição. Exemplos de bacias hidrográficas afluentes aos rios Alva e Alvoco (serras do Açor e Estrela) ". in Riscos Ambientais e Formação de Professores. Colectâneas Cindínicas VII, Núcleo de Investigação Cientifica de Incêndios Florestais, Coimbra, pp.199-223;

Gallo, MárioAmaro dos Santos (1929-1930) - Apontamentos de hidráulica florestal. Direcção Geral dos Serviços Florestais e Aquícolas;

Gallo, Mário Amaro dos Santos (1942a) - “Algumas considerações sobre erosão e correção torrencial. Um novo tipo de barragens para a correção torrencial." Comunicação apresentada no Congresso Luso-Espanhol para o Progresso das Ciências. Portugal, 56 p.;

Gallo, Mário Amaro dos Santos (1942b) - Correção torrencial da Bacia Hidrográfica do Rio Liz. 
Texto. Vol. 1, Direcção Geral dos Serviços Florestais e Aquícolas, 196p.;

Gallo, Mário Amaro dos Santos (1942c) - Correção torrencial da Bacia Hidrográfica do Rio Liz. Fotografias. Vol. 3, Direcção Geral dos Serviços

Gallo, Mário Amaro dos Santos (1960) - Resenha dos Trabalhos de Correcção Torrencial Realizados em Portugal. Direcção Geral dos Serviços Florestais e Aquícolas, 13 p.;

GuerReiro, M. Gomes (1953) - A floresta na conservação do solo e da água. Coleção "a Terra e o Homem", Lisboa, 193 p.;

Guiomar, Nuno e Fernandes, João Paulo (2009) "Minimización de impactos a corto plazo tras incendio: la importancia de las técnicas de Bioingeniería. Ates II Congrés de SPV e VI Congrés de la Asociación de Ingeniería del Paisaje, Girona;

INAG (2002) - "Plano de Bacia Hidrográfica do Rio Mondego. Síntese da análise e diagnóstico da situação actual”. Volume I, Ministério do Ambiente e do Ordenamento do Território, INAG, Lisboa. 203p.;

LAL, R. (1998) - "Soil erosion impact in agronomic productivity and environment quality: Critical Review”. Plant Science, vol. 17, p. $319-464$

Lourenço, Luciano (1988a) “Efeitos da erosão acelerada em vertentes na sequência de incêndios florestais". Comunicações, Jornadas Científicas sobre Incêndios Florestais, vol.II, Coimbra, p. 5.1.-1 a 20.

LouREnço, Luciano (1988b) “Efeitos do temporal de 23 de junho de 1988 na intensificação da erosão das vertentes afectadas pelo incêndio florestal de Arganil/Oliveira do Hospital". Comunicações e Conclusões, Seminário Técnico sobre Parques e Conservação da Natureza nos Países do Sul da Europa, Faro, p. 43-77 e em separata, III Semana de Geografia Física, Coimbra, 35 p.;

Lourenço, Luciano (2004) - Riscos de Erosão após Incêndios Florestais. Coletâneas Cindínicas V, Núcleo de Investigação científica de Incêndios Florestais, Coimbra, 199 p.;
Lourenço, Luciano; Bento-Gonçalves, António e Monteiro, Rui (1990) - “Avaliação da erosão dos solos produzida na sequência de incêndios florestais". Comunicações, II Congresso Florestal Nacional, Porto, II vol, p. 834-844;

MAYER, Ruy (1941) - Noções de hidráulica florestal. Direcção Geral de Serviços Florestais e Aquícolas, 132 p.;

Mendonça, Varannes (1951) - Lições de hidráulica florestal. Instituto Superior de Agronomia, Lisboa, Portugal;

Mota, José Luís das Neves (1973) - Relatório de tirocínio do Curso de Regente Agrícola. Escola de Regentes Agrícolas de Santarém. 58 p.;

Pardal, Sidónio (2012) - “Ordenamento dos Espaços silvestres: passar do plano ao desdobramento". Comunicação no Workshop Regime de Arborização e Rearborização, AFN-ICNB, Auditório da Torre do Tombo, 44p.;

Pruskı, F. (2000) - “Aplicação de modelos físicomatemáticos à engenharia de conservação de água e solo". Agricultura, Sustentabilidade e o Semi-Árido, 1, Fortaleza, p. 233-296;

Quintas, Fernando Eduardo Geraldes (2002) - Planeamento da Construção de Barragens de Terra. Dissertação de Mestrado da Faculdade de Engenharia da Universidade do Porto, Porto, 174 p.;

Roxo, M. (2001) - “O centro experimental de erosão de Vale Formoso, Mértola. Estudos experimentais de erosão hídrica de solos". Metodologias de Estudo de Processos de Erosão dos Solos, Porto, p. 32-45;

Silva, M.; Curi, N.; Ferreira, M.; Lima, J.; Marques, J.; LimA, L. A. (1995) - "Resistência ao salpico provocado por impacto de gostas de chuva simulada em Latossolos e sua relação com características químicas e mineralógicas". Ciência e Prática, v.19, n. ${ }^{\circ}$, p. 176-182;

WASSON, R. (1987) - "Detection and measurement of land degradation". Land Degradation - problems and policies, Cap. 1.3, Physical and biological aspects of land degradation. 